\title{
Characteristics of aerosol pollution during heavy haze events in Suzhou, China
}

\author{
Mi Tian ${ }^{1}$, Huanbo Wang ${ }^{1}$, Yang Chen ${ }^{1}$, Fumo Yang ${ }^{1,2,3}$, Xiaohua Zhang ${ }^{4}$, Qiang Zou ${ }^{4}$, Renquan Zhang ${ }^{4}$, \\ Yongliang $\mathrm{Ma}^{5}$, and Kebin $\mathrm{He}^{5}$ \\ ${ }^{1}$ Key Laboratory of Reservoir Aquatic Environment of CAS, Chongqing Institute of Green and Intelligent Technology, \\ Chinese Academy of Sciences, Chongqing 400714, China \\ ${ }^{2}$ Center for Excellence in Urban Atmospheric Environment, Institute of Urban Environment, Chinese Academy of Sciences, \\ Xiamen 361021, China \\ ${ }^{3}$ Changjiang Normal University, Chongqing 408100, China \\ ${ }^{4}$ Suzhou Environmental Monitoring Center, Suzhou 215004, China \\ ${ }^{5}$ School of Environment, Tsinghua University, Beijing 100012, China
}

Correspondence to: Fumo Yang (fmyang@cigit.ac.cn)

Received: 30 September 2015 - Published in Atmos. Chem. Phys. Discuss.: 26 November 2015

Revised: 6 May 2016 - Accepted: 24 May 2016 - Published: 14 June 2016

\begin{abstract}
Extremely severe haze weather events occurred in many cities in China, especially in the east part of the country, in January 2013. Comprehensive measurements including hourly concentrations of $\mathrm{PM}_{2.5}$ and its major chemical components (water-soluble inorganic ions, organic carbon (OC), and elemental carbon (EC)) and related gas-phase precursors were conducted via an online monitoring system in Suzhou, a medium-sized city in Jiangsu province, just east of Shanghai. $\mathrm{PM}_{2.5}$ (particulate matter with an aerodynamic diameter of $2.5 \mu \mathrm{m}$ or less) frequently exceeded $150 \mu \mathrm{g} \mathrm{m}^{-3}$ on hazy days, with the maximum reaching $324 \mu \mathrm{g} \mathrm{m}^{-3}$ on 14 January 2013. Unfavorable weather conditions (high relative humidity $(\mathrm{RH})$, and low rainfall, wind speed, and atmospheric pressure) were conducive to haze formation. High concentrations of secondary aerosol species (including $\mathrm{SO}_{4}^{2-}, \mathrm{NO}_{3}^{-}, \mathrm{NH}_{4}^{+}$, and $\mathrm{SOC}$ ) and gaseous precursors were observed during the first two haze events, while elevated primary carbonaceous species emissions were found during the third haze period, pointing to different haze formation mechanisms. Organic matter $(\mathrm{OM}),\left(\mathrm{NH}_{4}\right)_{2} \mathrm{SO}_{4}$, and $\mathrm{NH}_{4} \mathrm{NO}_{3}$ were found to be the major contributors to visibility impairment. High concentrations of sulfate and nitrate might be explained by homogeneous gas-phase reactions under low RH conditions and by heterogeneous processes under relatively high RH conditions. Analysis of air mass trajectory clustering and potential source contribution function showed
\end{abstract}

that aerosol pollution in the studied areas was mainly caused by local activities and surrounding sources transported from nearby cities.

\section{Introduction}

Haze is defined as visibility lower than $10 \mathrm{~km}$ when relative humidity $<80 \%$. Rapidly increased air pollution in China in the past several decades has resulted in frequent occurrences of haze events, which has caused great concern to the scientific community as well as the public (Zhang et al., 2012). Haze events have adverse effects on human health, traffic, climate, and other important aspects (Zhang et al., 2015; Charlson et al., 1987; Ramanathan and Vogelmann, 1997; Tegen et al., 2000; Yu et al., 2002; Tie et al., 2009a, b). Fine particles $\left(\mathrm{PM}_{2.5}\right.$, particulate matter with an aerodynamic diameter of $2.5 \mu \mathrm{m}$ or less) are largely responsible for haze formation due to their ability for light extinction including scattering and absorbing solar and infrared radiation (Yu et al., 2014). Light extinction of $\mathrm{PM}_{2.5}$ is highly associated with its chemical composition (Tao et al., 2014). Water-soluble inorganic ions and carbonaceous species often account for major fractions of $\mathrm{PM}_{2.5}$ and are important contributors to visibility impairment (Tan et al., 2009; Pathak et al., 2009), and thus have been investigated extensively (Yang et al., 2005; 
Jansen et al., 2014; Pathak et al., 2009). Most existing studies were based on filter sampling and offline analysis and had limitations in providing detailed insight into the roles major chemical species play during shorter haze periods.

High contributions of secondary inorganic aerosols (SIAs, including sulfate, nitrate, and ammonium), the predominant water-soluble ionic species in $\mathrm{PM}_{2.5}$, to visibility reduction have been observed in many cities in China (Huang et al., 2014). Gas- or liquid-phase reactions of sulfur dioxide and nitrogen oxides are the primary mechanisms forming aerosol sulfate and nitrate. For the formation of sulfate, homogeneous gas-phase reaction of $\mathrm{SO}_{2}$ with $\mathrm{OH}$ radicals, and heterogeneous reactions in the aqueous surface layer of preexisting particles and in-cloud processes, are the primary mechanisms (Wang et al., 2006). The rates of gas-phase and liquid-phase reactions of $\mathrm{SO}_{2}$ were similar in summer, while the heterogeneous processes were responsible for the oxidation in winter (Hewitt, 2001). Nitric acid can be formed from homogeneous gas-phase reactions of $\mathrm{NO}_{2}$ with $\mathrm{OH}$ or $\mathrm{O}_{3}$ and from heterogeneous hydrolysis of $\mathrm{N}_{2} \mathrm{O}_{5}$, which occurred predominantly during daytime and nighttime, respectively (Khoder, 2002). Both sulfuric acid and nitric acid react with alkaline substances in the atmosphere, mostly ammonia, under ambient conditions to produce salts (Hewitt, 2001). The neutralization of sulfuric acid by ammonia has been found to be preferred over the formation of ammonium nitrate (Warneck, 1999). Thus, the formation of ammonium nitrate in fine particles is usually under significantly neutralized or ammonium-rich conditions (Pathak et al., 2009). There are various factors influencing the formation of aerosol sulfate and nitrate, such as the levels of gaseous precursors $\left(\mathrm{SO}_{2}, \mathrm{NH}_{3}, \mathrm{NO}_{x}\right)$ and oxidants, the characteristics of preexisting aerosols, and meteorological conditions. These factors may vary by location, resulting in different formation mechanisms in different areas. For instance, different formation pathways have been reported for nitrate in ammonia-rich and ammonia-deficient areas (Pathak et al., 2009).

In January 2013, extremely severe, persistent, and widespread haze weather occurred in 10 provinces in central and eastern China. These serious pollution events not only had great adverse effects on human health, as seen in a sharp increase in respiratory diseases, but also caused immeasurable economic loss (Huang et al., 2014; Chen et al., 2013). High secondary inorganic and organic aerosol contributions to particulate pollution during these haze events were reported in a recent study based on measurements at urban sites in Beijing, Shanghai, Guangzhou, and Xi' an, which are located in the northern, eastern, southern, and western regions of China, respectively (Huang et al., 2014). In addition to investigating primary particulate emissions, the formation mechanisms of these secondary species and related affecting factors also need to be understood in order to control $\mathrm{PM}_{2.5}$ levels in China.

The Yangtze River Delta (YRD), the Pearl River Delta, Beijing-Tianjin-Tangshan, and the Sichuan Basin are the four regions with the strongest haze influence in China. The characteristics and formation mechanisms of haze in the YRD are different from other haze regions, such as Beijing and the Pearl River Delta (Fu et al., 2008). Suzhou is located in the heartland of the YRD region and is an important city. It suffered from extremely serious aerosol pollution in January 2013. With tremendous economic growth over the past 30 years, Suzhou has experienced high levels of air pollution as reflected in the frequency of haze occurrence. The annual haze days in Suzhou increased from only 2 days to more than 150 days from 1956 to 2011 ; i.e., over $40 \%$ of days were hazy in 2011. The low visibility, particularly the haze, has become a major concern of the city. However, only a few studies have focused on haze events in Suzhou and little is known about the chemical characteristics and sources of fine particles in this city. To fill these knowledge gaps, an intensified monitoring campaign was launched from December 2012 to January 2013 to collect high temporal resolution chemical and meteorological data. The objectives of this study are to (1) identify the dominant species in $\mathrm{PM}_{2.5}$ and which are responsible for the visibility reduction; (2) explore the formation mechanism of the aerosol pollution; (3) study the impact of local, nearby, and remote sources on the formation of haze in urban Suzhou.

\section{Methodology}

\subsection{Field observations}

The sampling station was set up at the roof of one building in Suzhou Institute of Environmental Sciences $\left(31^{\circ} 20^{\prime} \mathrm{N}\right.$, $120^{\circ} 36^{\prime}$ E) (Fig. 1), about $300 \mathrm{~m}$ west of Nanyuan South Road and $360 \mathrm{~m}$ north of South Ring Road Elevated Bridge. There is no industrial source nearby and the site is representative of an urban residential and commercial environment. Suzhou is located in the center of Yangtze River Delta (YRD), about $80 \mathrm{~km}$ east of Shanghai and $200 \mathrm{~km}$ west of Nanjing.

Online hourly $\mathrm{PM}_{2.5}$ mass concentrations were measured using a tapered element oscillating microbalance (TEOM1405, Thermo Scientific Corp., MA, US) with a heating temperature of $50{ }^{\circ} \mathrm{C}$. Some of the volatile particulate matter might be lost at $50^{\circ} \mathrm{C}$, but comparisons with collocated filters showed that the loss was less than $10-20 \%$ of the gravimetric mass (Chow et al., 2008).

Hourly real-time concentrations of five cations $\left(\mathrm{Na}^{+}, \mathrm{K}^{+}\right.$, $\mathrm{NH}_{4}^{+}, \mathrm{Ca}^{2+}$, and $\left.\mathrm{Mg}^{2+}\right)$ and four anions $\left(\mathrm{F}^{-}, \mathrm{Cl}^{-}, \mathrm{NO}_{3}^{-}\right.$, and $\mathrm{SO}_{4}^{2-}$ ) in $\mathrm{PM}_{2.5}$ were determined by the URG Series 9000 Ambient Ion Monitor (AIM, URG Corporation, Chapel Hill, NC). The system consists of a particle collection unit and two ion chromatograph analyzers for cation and anion analyses. $\mathrm{PM}_{2.5}$ was separated by a sharp-cut cyclone inlet operating at a flow rate of $3 \mathrm{~L} \mathrm{~min}^{-1}$. The air was drawn through a liquid diffusion parallel-plate denuder to remove the inter- 


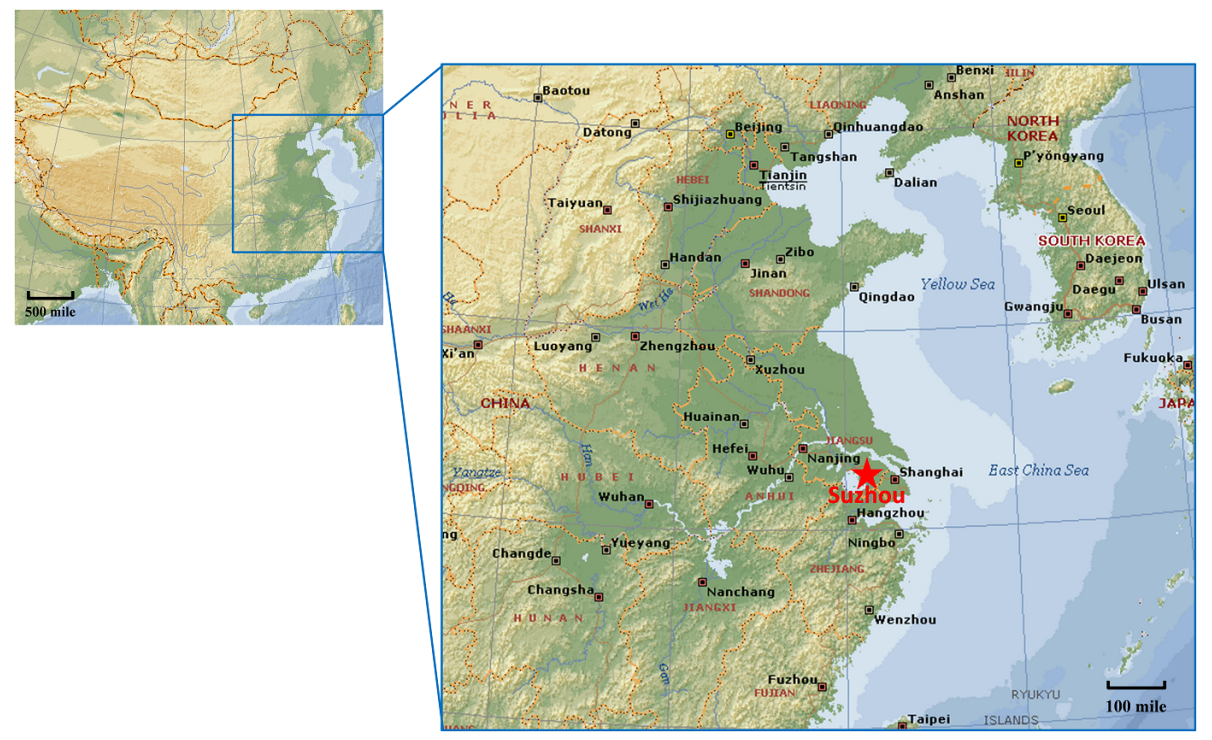

Figure 1. The sampling site in Suzhou. The locations of major cities with a population of more than 1 million (such as Qingdao, Nanjing, and Hangzhou) are marked with a square symbol. The topographical map was derived from Microsoft ${ }^{\circledR}$ Encarta $^{\circledR} 2009^{\circledR} 1993-2008$.

fering acidic and basic gases. A Steam Jet Aerosol Collector was placed downstream of the denuder for collection and extraction of particles. The water extract was subsequently injected into the two ion chromatograph analyzers once an hour. The estimated uncertainties of the AIM measurements were approximately less than $15 \%$ (Trebs et al., 2004; Pathak et al., 2011). Some measures were taken out to reduce error; for instance, standards solutions were periodically injected to check the consistency of sensitivity of the detectors and air flow rate is frequently checked using a calibrated flow meter.

A semi-continuous OC/EC (organic carbon/elemental carbon) analyzer (Sunset Laboratory, Forest Grove, Oregon, USA) was applied to determine the carbonaceous species in $\mathrm{PM}_{2.5}$. This instrument used the thermal-optical transmittance method based on the NIOSH Method 5040. Organic compounds were vaporized in pure helium and then oxidized to $\mathrm{CO}_{2}$ in a manganese dioxide oxidizing oven. $\mathrm{CO}_{2}$ was then quantified by a non-dispersive infrared detector. EC was then desorbed in an oxygen blend carrier gas and then oxidized and quantified using the same method as for OC. The split point between the pyrolyzed carbon formed from the organic carbon during the heating and EC that was originally in the sample was determined by measuring the transmission of a laser beam through the filter. A certain volume of methane was injected, oxidized, and quantified as an internal standard. Good correlations were found between the data measured by this instrument and filter-based laboratory analyses (Bae et al., 2004).

Visibility was monitored using the Belfort Model 6000 Visibility Sensor (Belfort Instrument Corp., MD, US). Trace $\mathrm{O}_{3}, \mathrm{SO}_{2}, \mathrm{NO}-\mathrm{NO}_{2}-\mathrm{NO}_{x}$, and $\mathrm{CO}$ gases were obtained with a resolution of $1 \mathrm{~h}$ by applying online analyzers (Thermo In- struments, TEI 49i, 43i, 42i, and 48i, respectively). Meteorological parameters were collected using Met Station One (Met One Corp., OR, US).

\subsection{Data analysis methods}

\subsubsection{Reconstruction of the light extinction coefficient}

The light extinction $\left(b_{\text {ext }}\right)$ which is the sum of light scattering by particle $\left(b_{\mathrm{s}, \mathrm{p}}\right)$, absorption by particle $\left(b_{\mathrm{a}, \mathrm{p}}\right)$, scattering by gas $\left(b_{\mathrm{s}, \mathrm{g}}\right)$, and absorption by gas $\left(b_{\mathrm{a}, \mathrm{g}}\right)$, is reconstructed according to the revised IMPROVE algorithm as follows (Pitchford et al., 2007):

$$
\begin{aligned}
b_{\text {ext }} & =b_{\mathrm{s}, \mathrm{p}}+b_{\mathrm{a}, \mathrm{p}}+b_{\mathrm{a}, \mathrm{g}}+b_{\mathrm{s}, \mathrm{g}} \\
& \approx 2.2 \times f_{\mathrm{S}}(\mathrm{RH}) \times\left[\text { small }\left(\mathrm{NH}_{4}\right)_{2} \mathrm{SO}_{4}\right] \\
& +4.8 \times f_{\mathrm{L}}(\mathrm{RH}) \times\left[\operatorname{large}\left(\mathrm{NH}_{4}\right)_{2} \mathrm{SO}_{4}\right] \\
& +2.4 \times f_{\mathrm{S}}(\mathrm{RH}) \times\left[\text { small } \mathrm{NH}_{4} \mathrm{NO}_{3}\right] \\
& +5.1 \times f_{\mathrm{L}}(\mathrm{RH}) \times\left[\operatorname{large} \mathrm{NH}_{4} \mathrm{NO}_{3}\right] \\
& +2.8 \times[\text { small OM}]+6.1 \times[\text { large } \mathrm{OM}] \\
& +1 \times[\text { fine soil }]+1.7 \times f_{\mathrm{SS}}(\mathrm{RH}) \times[\text { sea salt }] \\
& +0.6 \times[\text { coarse mass }]+10 \times[\mathrm{EC} \text { mass }] \\
& +0.33 \times\left[\mathrm{NO}_{2}(\mathrm{ppb})\right]+\text { Rayleigh scattering },
\end{aligned}
$$

where $f_{\mathrm{S}}(\mathrm{RH})$ and $f_{\mathrm{L}}(\mathrm{RH})$ are the water growth factors for small- and large-sized distribution of sulfate and nitrate, respectively, and $f_{\mathrm{SS}}(\mathrm{RH})$ is the water growth factor for sea salt. These water growth factors vary as a function of relative humidity (RH) and are adopted according to Pitchford et al. (2007). The constant numbers in the above equation are extinction efficiencies for each chemical species under dry conditions. $\left(\mathrm{NH}_{4}\right)_{2} \mathrm{SO}_{4}$ mass is estimated as 1.38 times 
$\mathrm{SO}_{4}^{2-}$ mass and $\mathrm{NH}_{4} \mathrm{NO}_{3}$ mass 1.29 times $\mathrm{NO}_{3}^{-}$mass, assuming that $\mathrm{SO}_{4}^{2-}$ and $\mathrm{NO}_{3}^{-}$are fully neutralized by $\mathrm{NH}_{4}^{+}$in the forms of $\left(\mathrm{NH}_{4}\right)_{2} \mathrm{SO}_{4}$ and $\mathrm{NH}_{4} \mathrm{NO}_{3}$, respectively, according to the revised IMPROVE method. Organic matter (OM) is estimated as 1.8 times of $\mathrm{OC}$ concentration to account for unmeasured fractions.

The concentrations of sulfate, nitrate, and $\mathrm{OM}$ are divided into small- and large-sized fractions in this algorithm. The size modes are described by log-normal mass size distributions with geometric mean diameter and geometric standard deviations. Concentrations of sulfate, nitrate, and $\mathrm{OM}$ in the large and small mode are estimated using the following equations (taking sulfate as an example):

$$
\begin{aligned}
& \text { [large } \left.\left(\mathrm{NH}_{4}\right)_{2} \mathrm{SO}_{4}\right]=\left[\text { total }\left(\mathrm{NH}_{4}\right)_{2} \mathrm{SO}_{4}\right]^{2} / 20, \\
& \left.\quad \text { for [total }\left(\mathrm{NH}_{4}\right)_{2} \mathrm{SO}_{4}\right]<20 \mu g \mathrm{~m}^{-3} \\
& \text { [large } \left.\left(\mathrm{NH}_{4}\right)_{2} \mathrm{SO}_{4}\right]=\left[\text { total }\left(\mathrm{NH}_{4}\right)_{2} \mathrm{SO}_{4}\right], \\
& \left.\quad \text { for [total }\left(\mathrm{NH}_{4}\right)_{2} \mathrm{SO}_{4}\right]>20 \mu \mathrm{g} \mathrm{m}{ }^{-3} \\
& \quad\left[\text { small }\left(\mathrm{NH}_{4}\right)_{2} \mathrm{SO}_{4}\right]=\left[\text { total }\left(\mathrm{NH}_{4}\right)_{2} \mathrm{SO}_{4}\right] \\
& \quad-\left[\text { large }\left(\mathrm{NH}_{4}\right)_{2} \mathrm{SO}_{4}\right] .
\end{aligned}
$$

\subsubsection{Air mass back trajectory}

To study the impact of local and regional sources on the aerosol pollution in Suzhou, $48 \mathrm{~h}$ back trajectories starting at $100 \mathrm{~m}$ from the sampling site were calculated using the NOAA HYSPLIT model. The back trajectories were calculated four times per day at starting times of 04:00, 10:00, 16:00, and 22:00 UTC, i.e., 12:00, 18:00, 00:00, and 06:00 local time (LT), respectively. The trajectory cluster analysis was based on the GIS-based software TrajStat (Wang et al., 2009).

\subsubsection{Potential source contribution function}

The potential source contribution function (PSCF) method is based on the results of the HYSPLIT model and can be used to identify the regional sources. The zone studied is divided into $i \times j$ small equal grid cells. The PSCF value for the $i j$ th grid cell is calculated as $\mathrm{PSCF}_{i j}=m_{i j} / n_{i j}$, where $n_{i j}$ is designated as the number of trajectory segment endpoints that fall in the $i j$ th cell and $m_{i j}$ is defined as the number of trajectory endpoints with pollutants' concentrations higher than a set criterion (Ashbaugh et al., 1985; Wang et al., 2009). In the present study, the average concentrations were treated as the criterion (Hsu et al., 2003). The PSCF values were multiplied by a weighting function $W_{i j}$ to reduce the effect of small values of $n_{i j}$ and to better reflect the uncertainty in the values for the cells with small $n_{i j}$ values. The weighting function $W_{i j}$ is defined as follows (Polissar et al., 1999):
$W_{i j}=\left\{\begin{array}{ll}1.00, & 80<n_{i j} \\ 0.70, & 20<n_{i j} \leq 80 \\ 0.42, & 10<n_{i j} \leq 20 \\ 0.05, & n_{i j} \leq 10\end{array}\right.$.

The PSCF value can be interpreted as the conditional probability that air masses with pollutants' concentrations greater than the set criterion pass through the $i j$ th cell during transport to the receptor site (Wang et al., 2009). That is, cells with high PSCF values are indicative of regions with high potential contributions to the pollution at the receptor site.

\section{Results and discussion}

\subsection{General characteristics of haze events}

As illustrated in Fig. 2, the visibility varied from a few hundred meters to more than $50 \mathrm{~km}$ with a minimum value of only $322 \mathrm{~m}$ on 15 January 2013, which was accompanied by high RH ( $82 \%)$. During the 2-month observation period, there were a total of 10 periods when visibility was below $10 \mathrm{~km}$. Excluding the five periods accompanied by precipitation, the other five periods were identified as haze events and all of these events occurred in January 2013. During the haze occurrence, hourly concentrations of $\mathrm{PM}_{2.5}$ often exceeded $150 \mu \mathrm{g} \mathrm{m}^{-3}$, with a maximum concentration of $324 \mu \mathrm{g} \mathrm{m}^{-3}$ observed on 14 January 2013. These concentrations were generally higher than those in normal periods. The daily concentrations of $\mathrm{PM}_{2.5}$ on haze days varied from 148 to $196 \mathrm{~g} \mathrm{~m} \mathrm{~m}^{-3}$, which were 1.97 to 2.61 times the Grade II criteria of the national ambient air quality standard $\left(75 \mu \mathrm{g} \mathrm{m}^{-3}\right)$. These values were comparable to that observed in Nanjing where the average $\mathrm{PM}_{2.5}$ was $175.6 \mu \mathrm{g} \mathrm{m}^{-3}$, but were slightly higher than those in some other cities in the YRD, where mean values were generally lower than $147.3 \mu \mathrm{g} \mathrm{m}^{-3}$ when haze occurred in January 2013 (Wang et al., 2014a; Y. Wang et al., 2014). The aerosol pollution which happened in northeastern regions of China such as in Beijing, Tianjin, and Shijiazhuang was much more severe; for instance, the daily and hourly concentrations of $\mathrm{PM}_{2.5}$ were up to 368 and $462 \mu \mathrm{g} \mathrm{m}^{-3}$ in Tianjin in 9 to 13 January 2013, and the maximum hourly value of approximately $1000 \mathrm{\mu g} \mathrm{m}^{-3}$ was recorded in Beijing and Shijiazhuang in January 2013 (Ji et al., 2014; Han et al., 2014; Wang et al., 2015).

Approximately $40 \%$ of the time in January 2013, haze weather criteria were met, whereas no haze appeared in December 2012. A low amount of rainfall in January might be one of the factors causing the long duration of haze. Relative humidity (RH) was reported to be an important contributor to the visibility reduction. In the present study, visibility decreased with increasing RH; e.g., when RH increased from 42 to $78 \%$, visibility decreased from $42 \mathrm{~km}$ at 14:00 LT on 17 January to $4 \mathrm{~km}$ at 07:00 LT on 19 January. Statistically, 


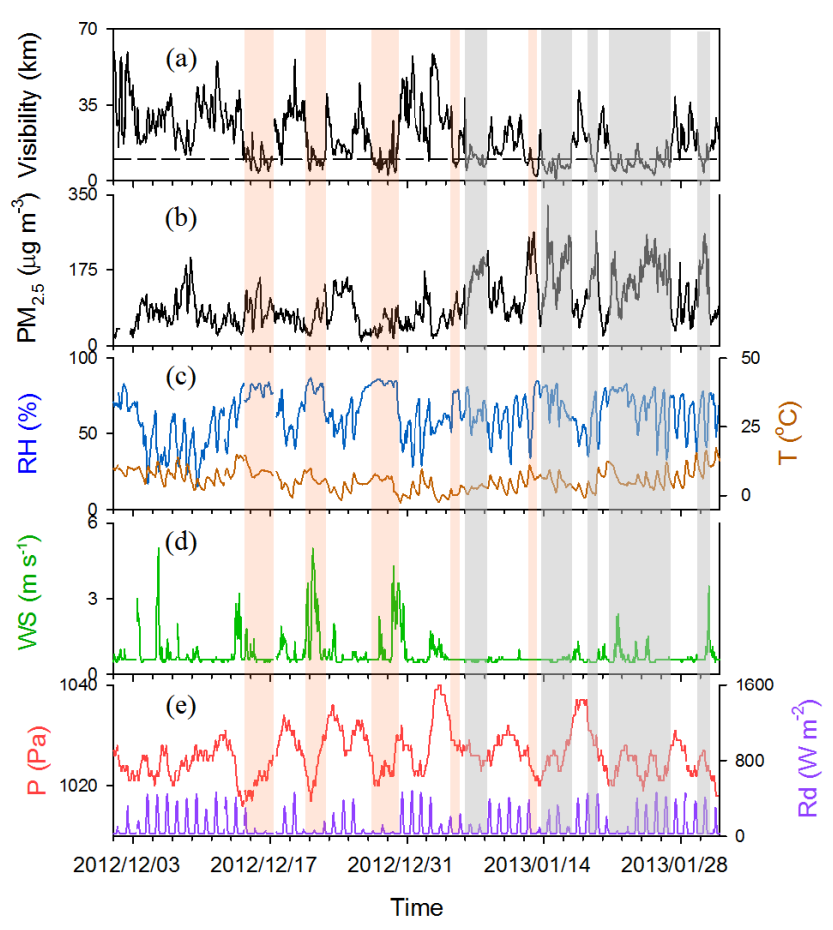

Figure 2. Time series of (a) visibility; (b) $\mathrm{PM}_{2.5}$ concentration; (c) relative humidity $(\mathrm{RH})$ and temperature $(T)$; (d) wind speed (WS) and pressure $(P)$; and (e) solar radiation (Rd). The shaded areas in orange represent periods when visibility was lower than $10 \mathrm{~km}$ and accompanied by precipitation. The shaded areas in gray represent haze periods.

RH was relatively higher during haze occurrence than clear periods. Low wind speed, lower than $5 \mathrm{~m} \mathrm{~s}^{-1}$, was frequently observed during this winter. Furthermore, wind speed was mostly less than $1 \mathrm{~m} \mathrm{~s}^{-1}$ during the haze events, lower than wind speeds in Beijing (Yang et al., 2015). In addition, atmospheric pressure was also found to be relatively low during the haze occurrences. The stagnant air, due to low wind speed and pressure, was unfavorable for aerosol horizontal transport or vertical diffusion, and therefore resulted in aerosol accumulation. Therefore, unfavorable weather conditions (high RH, and low rainfall, wind speed and atmospheric pressure) were among the causes forming haze in January 2013 in Suzhou as well as in many other cities (Wang et al., 2014b; J. Wang et al., 2014; Y. Wang et al., 2014; Han et al., 2014; Yang et al., 2015).

In order to obtain more insight into the haze formation in this region, three haze events, which occurred on 19 January, from 21 to 23 January, and on 30 January, respectively, are further discussed below. Generally, the meteorological parameters and aerosol pollution level were comparable during these three haze occurrences, except for the relatively lower $\mathrm{RH}$ and higher temperature in the third haze events.

\subsection{PM $_{2.5}$ chemical composition and light extinction}

\subsection{1 $\mathbf{P M}_{2.5}$ chemical composition}

The temporal variations of the concentrations of watersoluble inorganic ions (WSIIs) are illustrated in Fig. 3. The mean concentration of WSIIs (including four anions and five cations) was $48.8 \pm 24.6 \mu \mathrm{g} \mathrm{m}^{-3}$, accounting for $40 \%$ of $\mathrm{PM}_{2.5}$ mass concentration, slightly lower than that in Beijing which was $69.4 \pm 55.8 \mu \mathrm{g} \mathrm{m}^{-3}$, and accounting for $43 \%$ of $\mathrm{PM}_{2.5}$ (Tao et al., 2015). $\mathrm{SO}_{4}^{2-}$ was the most abundant species in WSIIs, with an averaged value of $21.1 \pm 13.5 \mu \mathrm{g} \mathrm{m}^{-3}$, followed by $\mathrm{NH}_{4}^{+}\left(13.9 \pm 5.69 \mu \mathrm{g} \mathrm{m}^{-3}\right)$ and $\mathrm{NO}_{3}^{-}\left(10.7 \pm 6.75 \mu \mathrm{g} \mathrm{m}^{-3}\right)$, accounting for 43,29 , and $21 \%$ of WSIIs, respectively. These secondary inorganic components in total constitute $93 \%$ of total WSIIs, close to the result in Beijing (Gao et al., 2015; Tao et al., 2015). The rest of ions, $\mathrm{Na}^{+}\left(1.36 \pm 0.43 \mu \mathrm{g} \mathrm{m}^{-3}\right)$, $\mathrm{K}^{+}\left(0.85 \pm 0.45 \mu \mathrm{g} \mathrm{m}^{-3}\right), \mathrm{Cl}^{-}\left(0.54 \pm 1.28 \mu \mathrm{g} \mathrm{m}^{-3}\right), \mathrm{Ca}^{2+}$ $\left(0.34 \pm 0.27 \mu \mathrm{g} \mathrm{m}^{-3}\right), \mathrm{F}^{-}\left(0.06 \pm 0.72 \mu \mathrm{g} \mathrm{m}^{-3}\right)$, and $\mathrm{Mg}^{2+}$ $\left(0.05 \pm 0.07 \mu \mathrm{g} \mathrm{m}^{-3}\right)$, each had a minor contribution $(<3 \%)$ to WSIIs.

$\mathrm{NO}_{3}^{-}$and $\mathrm{SO}_{4}^{2-}$ are mainly formed from the transformation of their respective gaseous precursor of $\mathrm{NO}_{x}$ and $\mathrm{SO}_{2}$ (Wang et al., 2005). The emission ratio of $\mathrm{NO}_{x}$ to $\mathrm{SO}_{2}$ was 17.2-52.6 for motor vehicles and 0.527-0.804 for stationary sources in the Yangtze River Delta, which means that the emissions of $\mathrm{SO}_{2}$ from motor vehicles were much less than $\mathrm{NO}_{x}$, but the emissions of $\mathrm{SO}_{2}$ from stationary sources such as power plants, industrial boilers, and furnaces were relatively higher than $\mathrm{NO}_{x}$ (Fu et al., 2008). Thus, the mass ratio of $\mathrm{NO}_{3}^{-} / \mathrm{SO}_{4}^{2-}$ could be used as an indicator of the relative importance of mobile and stationary sources of sulfur and nitrogen in the atmosphere (Arimoto et al., 1996). In the present study, the averaged ratios of $\mathrm{NO}_{3}^{-} / \mathrm{SO}_{4}^{2-}$ and $\mathrm{NO}_{x} / \mathrm{SO}_{2}$ were 0.59 and 5.68, respectively, indicating that emissions from vehicles and stationary sources were both important in Suzhou. The ratio of $\mathrm{NO}_{3}^{-} / \mathrm{SO}_{4}^{2-}$ in this study was lower than that in Beijing, but higher than ratios in Shanghai (0.43), Qingdao (0.35), Taiwan (0.20), and Guiyang (0.13) (Wang et al., 2006; Yao et al., 2002; Hu et al., 2002a; Fang et al., 2002; Xiao and Liu, 2004).

The $\mathrm{NO}_{3}^{-} / \mathrm{SO}_{4}^{2-}$ ratio was relatively higher for $20 \%$ worst visibility hours $(0.58)$ than $20 \%$ best visibility hours (0.54), suggesting that vehicle emission might play an important role in haze pollution. This was in agreement with the result in Guangzhou, where the $\mathrm{NO}_{3}^{-} / \mathrm{SO}_{4}^{2-}$ ratio was 1.02 under stagnation and 0.55 on normal days, but contrary to that in Beijing, where the ratio in haze days $(0.89)$ was lower than on normal days (0.96) (Tan et al., 2009; Wang et al., 2006). In the present study, $\mathrm{NO}_{x}$ concentration greatly exceeded that of $\mathrm{SO}_{2}$ during haze periods, coinciding with the result in Guangzhou, but disagreeing with that in Beijing (Tan et al., 2009). Previous studies have indicated that high $\mathrm{NO}_{x}$ emission may reduce the formation of $\mathrm{OH}$ and $\mathrm{H}_{2} \mathrm{O}_{2}$, 


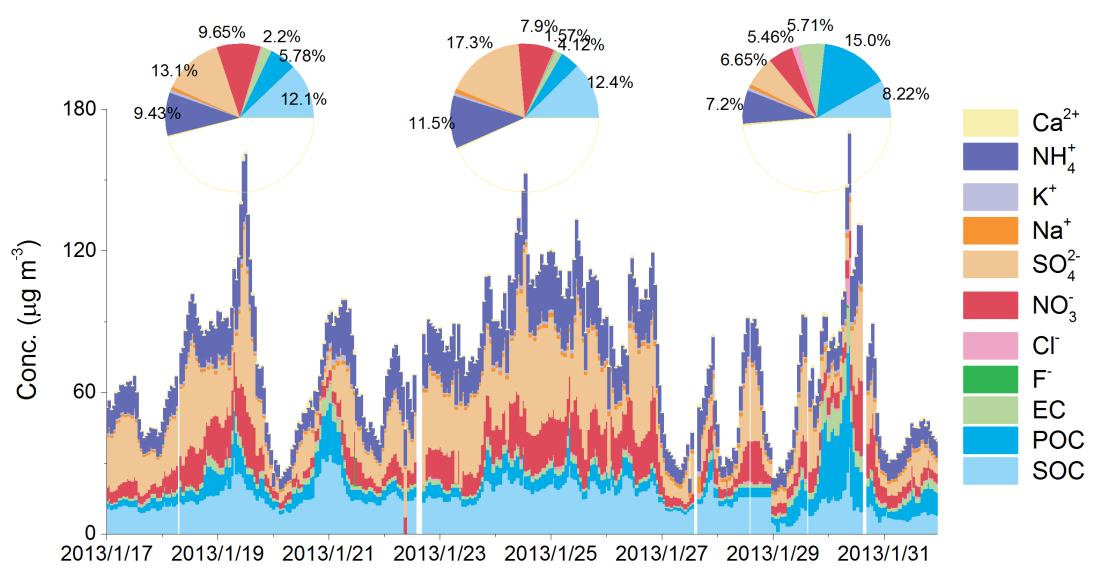

Figure 3. Temporal distribution of water-soluble inorganic ions and carbonaceous species. The aerosol composition in the three haze events was also illustrated in the pie chart.

and further decrease the possibility of $\mathrm{SO}_{4}^{2-}$ formation (Tan et al., 2009). Thus, the elevation of $\mathrm{NO}_{3}^{-}$concentration under worse visibility conditions was greater than that of $\mathrm{SO}_{4}^{2-}$ in both Suzhou and Guangzhou. The ratios of $\left(\mathrm{NO}_{3}^{-} / \mathrm{SO}_{4}^{2-}\right)$ to $\left(\mathrm{NO}_{x} / \mathrm{SO}_{2}\right)$ were lower for worse visibility periods, in accordance with that in Beijing, showing that the nitrate concentrations may also be greatly affected by the revolatilization of $\mathrm{NH}_{4} \mathrm{NO}_{3}$ (Tan et al., 2009).

The carbonaceous species, constituting $22 \%$ of $\mathrm{PM}_{2.5}$, were dominated by organic carbon, which was $22.8 \pm 10.6 \mu \mathrm{g} \mathrm{m}^{-3}$ and 3 to 29 times of that of elemental carbon $\left(2.79 \pm 2.58 \mu \mathrm{g} \mathrm{m}^{-3}\right)$, similar to species in Beijing (Tao et al., 2015). The relatively high ratios of OC/EC $(10.6 \pm 4.29)$, which were higher than the ratios in Beijing $(7.1 \pm 0.5)$ and Jinan $(7.15 \pm 1.78)$, demonstrated the existence of secondary organic carbon (SOC) (Ji et al., 2014; Zhang et al., 2014). The concentrations of SOC were estimated by applying the EC tracer method, which has been widely used to estimate the secondary organic aerosol contribution to $\mathrm{PM}_{2.5}$ concentrations (Castro et al., 1999; Yang et al., 2005). The minimum ratio of OC / EC was 3.09 in the present study. The estimated SOC was $14.2 \pm 5.69 \mu \mathrm{g} \mathrm{m}^{-3}$, contributing $65 \%$ on average to OC. The SOC/OC was higher than 0.5 during almost the whole sampling period, except on 30 January when the third haze event occurred. This ratio was higher than most of the results found in other areas such as in Beijing and Guangzhou (Yang et al., 2005; Tan et al., 2009).

Major components in $\mathrm{PM}_{2.5}$ were found to be $\mathrm{SO}_{4}^{2-}$ $(17 \%), \mathrm{SOC}(14 \%), \mathrm{NH}_{4}^{+}(12 \%), \mathrm{NO}_{3}^{-}(8 \%)$, and primary organic carbon (POC) $(6 \%)$. The top four components were mainly from secondary sources. $\mathrm{PM}_{2.5}$ was significantly correlated with these secondary species, revealing that gas to particle conversion was severe in winter and had great impact on aerosol pollution in this region. It is worth noting that the aerosol composition in the third haze event was distinct from the other two (Fig. 3) as seen from the higher proportion of carbon species from primary emissions (POC and EC) and lower fraction of secondary formation components (SIA and SOC), indicating different haze formation mechanisms in the third haze event.

\subsubsection{Light extinction coefficient}

In order to determine the contribution of $\mathrm{PM}_{2.5}$ constituents to the visibility degradation, light extinction $\left(b_{\text {ext }}\right)$ was reconstructed based on the revised IMPROVE algorithm. In the present study, the impacts of fine soil and coarse mass were not included because of the lack of metal elements and coarse matter concentrations. The estimated $b_{\text {ext }}$ was $664 \pm 288 \mathrm{Mm}^{-1}$ and was significantly correlated with $\mathrm{PM}_{2.5}$ concentrations $(r=0.94, p<0.001)$, demonstrating the strong influence of fine aerosols on visibility degradation.

The reconstructed light extinction coefficient was compared with that derived from visibility and that calculated using a regression model developed by Chen. Extinction coefficient is inversely correlated with visibility according to the Koschmieder equation (Vis $=K / b_{\text {ext }}$ ) (Seinfeld and Pandis, 2012). By using a $K$ value of 3.912, the calculated $b_{\text {ext }}$ was $371 \pm 234 \mathrm{Mm}^{-1}$, much lower than the coefficients obtained from IMPROVE algorithm. Nevertheless, they were significantly correlated with each other $(r=0.71, p<0.001)$. Another method applied here to estimate $b_{\text {ext }}$ was a two-factor parameterization regression model based on $\mathrm{RH}$ and aerosol volume concentration (Chen et al., 2012). The volume concentration can be acquired from the mass concentration divided by an average particle density of $1.7 \mathrm{~g} \mathrm{~cm}^{-1}$ (Wehner et al., 2008). A comparison of $b_{\text {ext }}$ reconstructed by IMPROVE algorithm and the regression model is presented in Fig. 4. Generally, a strong correlation was evident with a correlation coefficient higher than $0.97\left(R^{2}=0.952\right)$, confirming that the reconstructed $b_{\text {ext }}$ from the IMPROVE algorithm was reliable. The majority of $b_{\text {ext }}$ was clustered near the $1: 1$ line 


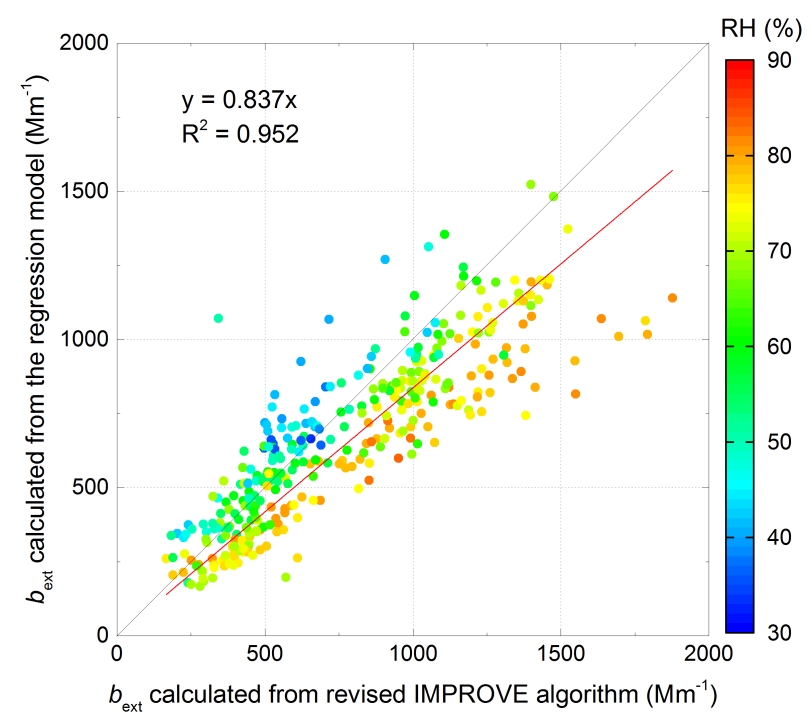

Figure 4. Comparison of the calculated $b_{\text {ext }}$ between those obtained from the regression equation and those from the IMPROVE algorithm.

for $b_{\text {ext }}<500 \mathrm{Mm}^{-1}$, with the corresponding RH mainly below $75 \%$. However, for $b_{\text {ext }}>500 \mathrm{Mm}^{-1}$, the dispersion of $b_{\text {ext }}$ gradually increased, and most of the corresponding RH was higher than $75 \%$. There are two possibilities causing these deviations. The first one is the ignorance of the impact of particle size distribution on light extinction in the twofactor parameterization model applied here, as the variation of aerosol mass or volume fractions of different size particles can influence the $b_{\text {ext }}$ value, especially under high RH (Chen et al., 2012). The second one is from the uncertainties of in situ measurements since the RH sensor may have large errors under high RH conditions. The regression model result was directly controlled by the RH value, and the hygroscopic growth factor in the IMPROVE algorithm depends on RH.

The light extinction was mostly influenced by aerosol light scattering as the estimated $b_{\mathrm{s}, \mathrm{p}}$ was $609 \pm 277 \mathrm{Mm}^{-1}$, accounting for $91 \%$ of $b_{\text {ext }}$, while $b_{\mathrm{a}, \mathrm{p}}$ and the extinction coefficient by gaseous species were only $27.9 \pm 25.8$ and $26.6 \pm 4.87 \mathrm{Mm}^{-1}$, respectively. The largest contributor to $b_{\text {ext }}$ from the reconstructed chemical species in fine particles was organic matter (OM), accounting for $40 \%$, followed by $\left(\mathrm{NH}_{4}\right)_{2} \mathrm{SO}_{4}, 34 \%, \mathrm{NH}_{4} \mathrm{NO}_{3}, 16 \%$, and $\mathrm{EC}, 4 \%$. However, the percentage contributor varied greatly during the study period; e.g., the contributions of $\mathrm{NH}_{4} \mathrm{NO}_{3}$ ranged from only 3 to up to $40 \%$. Generally, the contributions of $\left(\mathrm{NH}_{4}\right)_{2} \mathrm{SO}_{4}$ and $\mathrm{NH}_{4} \mathrm{NO}_{3}$ were higher under low visibility periods, increased from 30 and $11 \%$, respectively, during the $20 \%$ best visibility periods to 39 and $19 \%$, respectively, during the $20 \%$ worst visibility period. Correspondingly, the contributions of $\mathrm{OM}$ and EC reduced from 46 and $5 \%$, respectively, to 35 and $4 \%$, respectively, during the same periods. These results indicated the important role sulfate and nitrate play in haze formation.

The percentage contribution to light extinction from individual aerosol components also varied with haze event and visibility conditions. The percentage contributions of individual components during the best and worst $20 \%$ visibility hours in each of the three haze events are compared and shown in Fig. 5. During the first haze event (on 19 January), the contribution of $\mathrm{NH}_{4} \mathrm{NO}_{3}$ was 8 and $24 \%$ during the $20 \%$ best and worst visibility hours, respectively, while the corresponding numbers are 48 and $37 \%$ for OM. There were no significant differences between the two visibility categories for the contributions of $\left(\mathrm{NH}_{4}\right)_{2} \mathrm{SO}_{4}$ or EC. During the second haze event (from 21 to 26 January), the fractions were $1.8,1.5$ and 1.3 times higher for $\mathrm{NH}_{4} \mathrm{NO}_{3}$, $\left(\mathrm{NH}_{4}\right)_{2} \mathrm{SO}_{4}$ and $\mathrm{EC}$ respectively but 1.2 times lower for OM under $20 \%$ worst visibility conditions than those under $20 \%$ best visibility conditions during this time. Overall, $\left(\mathrm{NH}_{4}\right)_{2} \mathrm{SO}_{4}$ made a great contribution to the light extinction, and $\mathrm{NH}_{4} \mathrm{NO}_{3}$ showed the largest difference between $20 \%$ best and worst visibility conditions during these two haze events. Therefore, secondary inorganic aerosols, especially $\mathrm{NH}_{4} \mathrm{NO}_{3}$, were likely the key component for the impaired visibility for these two haze events. The elevated proportion of $\left(\mathrm{NH}_{4}\right)_{2} \mathrm{SO}_{4}$ and $\mathrm{NH}_{4} \mathrm{NO}_{3}$ during the heavy polluted period was also observed in Beijing (Tao et al., 2015; Wang et al., 2015; Zheng et al., 2015). A different trend of comparison between the best and worst visibility periods was found in the third haze event (on 30 January) than in the first two. In the third event, the percentage contributions of OM and EC increased during the worst visibility period compared to the best visibility period (from 40 to 49 and 6.8 to $11 \%$, respectively), while that of $\left(\mathrm{NH}_{4}\right)_{2} \mathrm{SO}_{4}$ decreased (from 28 to $19 \%$ ). Carbonaceous components played a more important role in visibility reduction in the third event. Therefore, there seems to be different formation mechanisms for haze events in Suzhou.

\subsection{Conversion from gas to particle phase}

\subsubsection{Variations of aerosol particles and precursors}

Figure 6 diagrams the diurnal variations of meteorological parameters, various aerosol components, gaseous precursors, and some other important gaseous species under three different visibility conditions: (1) all data, (2) visibility $\leq 10 \mathrm{~km}$, and (3) visibility $>10 \mathrm{~km}$. The daily variations of gas-phase compounds were different between species and were mainly controlled by the direct surface emissions (such as $\mathrm{NO}_{x}$, $\mathrm{SO}_{2}$, and $\left.\mathrm{CO}\right)$ or photochemical process $\left(\mathrm{O}_{3}\right)$. There was a distinct morning peak and a less distinct afternoon peak, consistent with morning and afternoon rush hours for $\mathrm{NO}_{x}$ and $\mathrm{CO}$. This might be related to the heavy traffic emissions in the rush hours and strong elevation of the planetary boundary layer heights at noon. In contrast, there was only one midday 


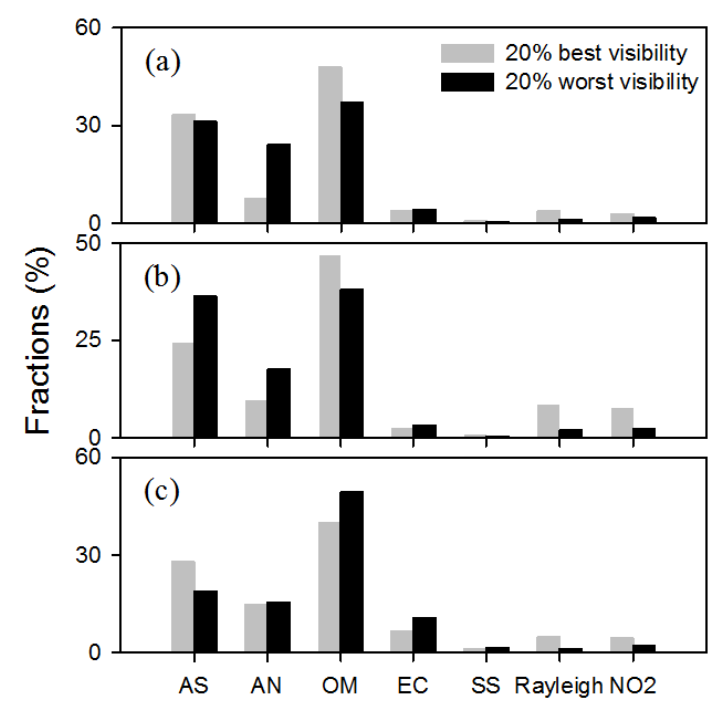

Figure 5. Relative contributions of various chemical components in $\mathrm{PM}_{2.5}$ (ammonium sulfate (AS), ammonium nitrate (AN), OM, and EC) to the total light extinction under $20 \%$ best and $20 \%$ worst visibility conditions during the first (a), second (b), and third (c) haze events.

peak for $\mathrm{SO}_{2}$. These diurnal profiles were similar to those observed in Guangzhou (Hu et al., 2002b) and Maryland (Antony Chen et al., 2001). In the latter study, the dominant source of $\mathrm{SO}_{2}$ was considered to be the long-range transport from the industrialized Midwest and with the deep boundary layer around noon; $\mathrm{SO}_{2}$ aloft mixed more effectively down to the surface and thus caused the midday peak of $\mathrm{SO}_{2}$. The reasons for the diurnal variation of $\mathrm{SO}_{2}$ observed in the present study need further investigation. Similar to the diurnal distribution of $\mathrm{SO}_{2}, \mathrm{O}_{3}$ also showed one distinct peak around noon due to the strong photochemistry at that time (Quan et al., 2014).

For the aerosol components, EC, which was also produced by the surface emissions, showed a profile similar to $\mathrm{NO}_{x}$ and CO. Furthermore, EC had significantly positive correlation with $\mathrm{NO}_{x}$ and $\mathrm{CO}$, demonstrating that they had common sources, mainly from vehicular exhaust. The diurnal profiles of the secondary species were similar to their precursors but obviously affected by other factors such as solar radiation, which could promote the oxidation of the precursors. For instance, there was a $2 \mathrm{~h}$ delay for sulfate to reach its peak compared to $\mathrm{SO}_{2}$ due to the transformation processes. This pattern was also observed in Guangzhou (Hu et al., 2002b). $\mathrm{NO}_{3}^{-}$and SOC exhibited similar diurnal variation as their precursors had common sources and they both formed from secondary photochemical oxidation. The daily profiles of $\mathrm{NO}_{3}^{-}, \mathrm{NH}_{4}^{+}$, and $\mathrm{SOC}$ showed lower concentrations around 15:00 (local time), probably due to the high boundary layer and/or low concentration of precursors. In addition, for $\mathrm{NO}_{3}^{-}$ and $\mathrm{NH}_{4}^{+}$, high temperature, which enhanced the evaporative loss, and low relative humidity may also be responsible for the low levels.

Figure 6 also suggests that both gas-phase compounds and aerosol components all showed similar patterns of diurnal variations but had different magnitudes of concentrations for different visibility levels. These components except for $\mathrm{O}_{3}$ all showed relatively higher concentrations under low visibility especially for the secondary inorganic species, indicating the important impact of the formation of secondary components on the visibility reduction. The relatively low levels of $\mathrm{O}_{3}$ under low visible conditions might be due to the decreased photochemical production and the chemical conversions of $\mathrm{SO}_{2}$ and $\mathrm{NO}_{x}$ to sulfate and nitrate. It is worth noting that the relatively high humidity which favored the formation of sulfate and nitrate was observed under low visibility conditions. In addition, it seemed that low visibility was associated with southwesterly wind. This might be related to the topography. There are mountains located on the southwest which is not conducive to the diffusion of pollutants.

In consideration of the distinct aerosol composition during the third haze event, a comparison of gaseous pollutants between the third and the first two haze episodes was done. The concentrations of $\mathrm{SO}_{2}$ and $\mathrm{O}_{3}$ were comparable for these three haze events. Contrarily, much higher levels of NO, CO and $\mathrm{NO}_{2}$ were evident during the third haze event, in accordance with the high concentrations of POC and EC. These species (NO, $\mathrm{CO}, \mathrm{NO}_{2}, \mathrm{POC}$, and $\mathrm{EC}$ ) had good correlations with each other. Furthermore, they had similar diurnal variations and exhibited extremely high levels in the morning rush hours on 30 January when the third haze event occurred. These results implied that there were common sources for these species, mainly from vehicle exhaust emissions.

\subsubsection{Formation mechanisms of sulfate and nitrate}

As discussed earlier, the chemical formation of sulfate and nitrate from $\mathrm{SO}_{2}$ and $\mathrm{NO}_{2}$ respectively, should play an important role in visibility reduction, especially for the first two haze events. The sulfur oxidation ratio, defined as $\mathrm{SOR}=n-$ $\mathrm{SO}_{4}^{2-} /\left(n-\mathrm{SO}_{4}^{2-}+n-\mathrm{SO}_{2}\right)$, and the nitrogen oxidation ratio, defined as $\mathrm{NOR}=n-\mathrm{NO}_{3}^{-} /\left(n-\mathrm{NO}_{3}^{-}+n-\mathrm{NO}_{2}\right)$, were used as indicators of the secondary transformation processes. The daily variations of NOR showed similar patterns to those of $\mathrm{NH}_{4}^{+}$and $\mathrm{NO}_{3}^{-}$. Likewise, SOR had similar diurnal changes as $\mathrm{SO}_{4}^{2-}$. The values of SOR and NOR increased more than 1.3 and 2.0 times, respectively, during the first two haze periods compared to clear periods, implying greater oxidation of gaseous species and more elevated secondary aerosols. This was supported by the evidently higher concentrations of $\mathrm{SO}_{4}^{2-}, \mathrm{NH}_{4}^{+}$, and $\mathrm{NO}_{3}^{-}$in the first two haze events. Almost no elevating levels of SOR, NOR, or SIA were observed in the third haze event, again confirming that SIA formation may not be the predominant factor controlling the occurrence of this haze event. 

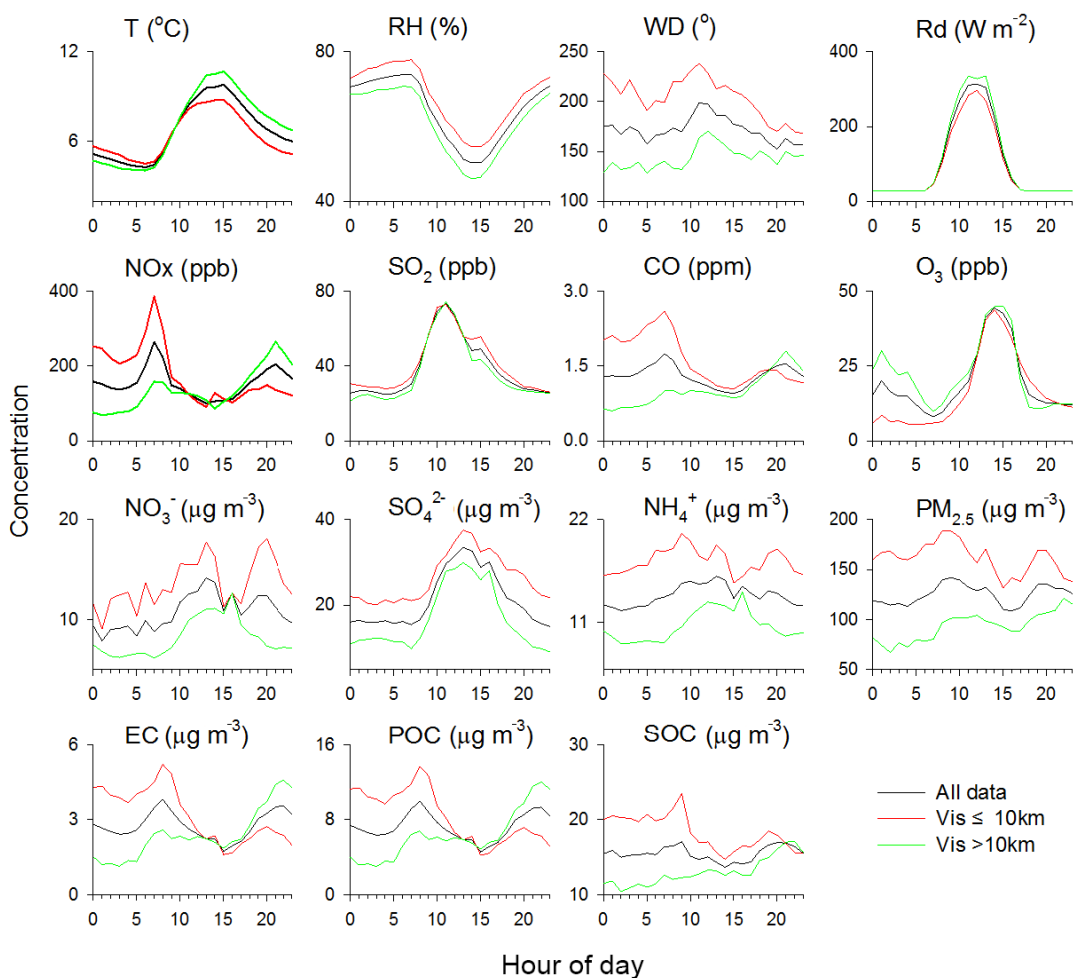

Figure 6. Diurnal profiles of meteorological variables, aerosol precursors $\left(\mathrm{NO}_{x}, \mathrm{SO}_{2}\right), \mathrm{CO}, \mathrm{O}_{3}, \mathrm{PM}_{2.5}$, and major aerosol compounds $\left(\mathrm{NO}_{3}^{-}\right.$, $\left.\mathrm{SO}_{4}^{2-}, \mathrm{NH}_{4}^{+}, \mathrm{EC}, \mathrm{POC}, \mathrm{SOC}\right)$ under different visibility conditions.

The formation of $\mathrm{SO}_{4}^{2-}$ from $\mathrm{SO}_{2}$ was mainly ascribed to the gas-phase oxidation by $\mathrm{OH}$ and $\mathrm{H}_{2} \mathrm{O}_{2}$ radical or heterogeneous oxidation (Wang et al., 2006; Zhao et al., 2013). The gas-phase reaction is a strong function of temperature and heterogeneous reactions always associated with high $\mathrm{RH}$ (Sun et al., 2006, 2014, 2013a). However, weak correlations were found between SOR and either temperature $(r=0.174$, $p<0.01)$ or RH $(r=0.150, p<0.01)$ in the present study, indicating the complex formation mechanism of sulfate.

Many studies suggested that sulfate from aqueous $\mathrm{SO}_{2}$ oxidation catalyzed by transition metals was more significant during winter haze rather than gas-phase oxidation (Li et al., 2011; Sun et al., 2013b; Zhao et al., 2013). Our measurement also found that heterogeneous oxidation was an important sulfate formation pathway in this study area. As shown in Fig. 7, high concentrations of $\mathrm{NO}_{2}$, accompanied by an ultra low level of $\mathrm{O}_{3}$ less than $10 \mathrm{ppb}$ and a low amount of solar radiation, were observed during most of the haze period, such as from 00:00 to 10:00 LT on 19 January and from 21 to 23 January. These results revealed the rather weak photochemical activities during these time windows. The high levels of $\mathrm{NO}_{2}$ and weak photochemical activities could result in insufficient production of oxidants $\left(\mathrm{OH}\right.$ and $\mathrm{H}_{2} \mathrm{O}_{2}$ radicals) for gas-phase oxidation (Hua et al., 2008). Thus, other oxidation reactions other than gas-phase oxidation likely explained the formation of abundant secondary sulfates during the haze episode. The high RH (>70\%) during these haze periods was a beneficial factor for aqueous-phase oxidation of $\mathrm{SO}_{2}$ to sulfate. Additionally, the calculation results using the Extended AIM Aerosol Thermodynamic Model (E-AIM, Model II) (Clegg et al., 1998) showed a significant increase of the liquid water content when $\mathrm{RH}>70 \%$. These results highlight the importance of the aqueous-phase reaction for the secondary transformation of $\mathrm{SO}_{2}$.

The concentrations of $\mathrm{O}_{3}$ were not extremely low during the whole haze period, such as during daytime on 23 and 25 January; the $\mathrm{O}_{3}$ levels were normal and had obvious diurnal variations with one distinct peak around noon. $\mathrm{RH}$ was lower than $70 \%$ and sulfate was primarily in the solid phase at these times, indicating that gas-phase oxidation was probably the dominant pathway for sulfate formation. Aqueousphase oxidation likely became predominant at night. This could explain the high SOR in the afternoon and the sustained high level at night.

Nitrate formation is mainly through gas-phase oxidation of $\mathrm{NO}_{2}$ by $\mathrm{OH}$ during daylight and the heterogeneous reactions of nitrate radical during nighttime (Seinfeld and Pandis, 2012). Figure 8 showed the nitrate to sulfate molar ratio $\left(\left[\mathrm{NO}_{3}^{-}\right] /\left[\mathrm{SO}_{4}^{2-}\right]\right)$ as a function of the ammonium to sulfate molar ratio $\left(\left[\mathrm{NH}_{4}^{+}\right] /\left[\mathrm{SO}_{4}^{2-}\right]\right)$, which can provide an insight into the formation pathway of the secondary species (Jansen et al., 2014; Pathak et al., 2009; 

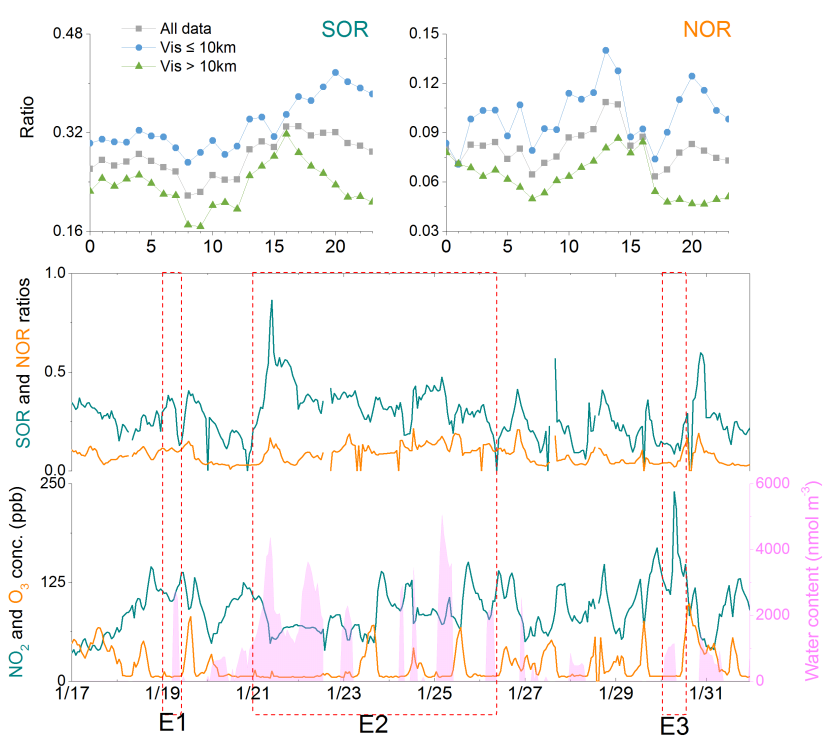

Figure 7. Temporary distributions of $\mathrm{SOR}, \mathrm{NOR}, \mathrm{NO}_{2}, \mathrm{O}_{3}$, and aerosol water content. Diurnal profiles of NOR and SOR ratios under different visibility conditions.

He et al., 2012). The relative abundance of nitrate linearly increased with the increasing ammonium to sulfate molar ratio. Fitting a linear regression line resulted in an intercept of $\left[\mathrm{NH}_{4}^{+}\right] /\left[\mathrm{SO}_{4}^{2-}\right]$ axis of 1.51 , indicating that nitrate formation via homogeneous reaction of $\mathrm{HNO}_{3}$ with $\mathrm{NH}_{3}$ became significant at $\left[\mathrm{NH}_{4}^{+}\right] /\left[\mathrm{SO}_{4}^{2-}\right]>1.51$ (Pathak et al., 2009; Jansen et al., 2014; He et al., 2012). Pathak et al. (2009) also reported an intercept value of 1.5 for several cities worldwide, while Jansen et al. (2014) found a slightly smaller intercept value of 1.38 for Hangzhou. The ammonium concentration in excess of the amount at which nitrate formation became evident was defined as excess ammonium $\left(\left[\mathrm{NH}_{4}^{+}\right]_{\text {exc }}=\left(\left[\mathrm{NH}_{4}^{+}\right] /\left[\mathrm{SO}_{4}^{2-}\right]-1.51\right) \times\left[\mathrm{SO}_{4}^{2-}\right]\right)$. The concentrations of excess ammonium were always higher than 0 and linearly correlated with nitrate concentration, as shown in Fig. 8. This indicated that the formation of nitrate was strongly associated with ammonium formation. In other words, when the excess ammonium was $>0$, the gas-phase homogeneous reaction between the ambient ammonia and nitric acid was responsible for forming nitrate (Pathak et al., 2009; Jansen et al., 2014). The slope of 0.37 for the regression and the scattering of the data indicated that the excess ammonium was bound to species other than nitrate, such as chloride, bisulfate, etc. The significance of gas-phase homogeneous reaction to nitrate formation has been reported for many cities (Jansen et al., 2014; Pathak et al., 2009). However, as mentioned above, in some cases during haze period, the conditions (ultra low ozone concentrations, low solar radiation, and high $\mathrm{NO}_{2}$ ) were not favorable for gas-phase oxidation. Relatively high RH levels were often observed in those cases, which may have favored the gas to particle partitioning of nitrate acid and ammonia (Sun et al., 2011).
Table 1. The percentages of air masses from each trajectory cluster and associated mean concentrations $\left(\mu \mathrm{g} \mathrm{m}^{-3}\right)$ of $\mathrm{PM}_{2.5}$ and its major chemical components, and mean $b_{\text {ext }}\left(\mathrm{Mm}^{-1}\right)$.

\begin{tabular}{lrrrrrr}
\hline & 1 & 2 & 3 & 4 & 5 & 6 \\
\hline Percentage (\%) & 20.6 & 31.7 & 20.6 & 12.7 & 6.3 & 7.9 \\
PM $_{2.5}$ & 129 & 117 & 167 & 103 & 84.0 & 87.4 \\
OC & 21.1 & 22.8 & 25.3 & 16.4 & 30.5 & 20.3 \\
EC & 2.05 & 3.87 & 2.21 & 1.45 & 3.90 & 1.86 \\
Sulfate & 22.9 & 18.2 & 32.4 & 23.1 & 8.85 & 8.39 \\
Nitrate & 11.5 & 10.0 & 16.9 & 7.84 & 3.26 & 7.91 \\
Ammonium & 15.2 & 12.3 & 18.9 & 12.4 & 7.93 & 9.88 \\
$b_{\text {ext }}$ & 675 & 597 & 921 & 556 & 548 & 463 \\
\hline
\end{tabular}

Furthermore, the E-AIM calculation results demonstrated that the nitrate partly or completely existed in the aqueous phase during those conditions. Therefore, we assumed that heterogeneous chemistry, such as heterogeneous hydrolysis of $\mathrm{N}_{2} \mathrm{O}_{5}\left(\mathrm{~N}_{2} \mathrm{O}_{5}+\mathrm{H}_{2} \mathrm{O}(\mathrm{aq}) \rightarrow 2 \mathrm{HNO}_{3}\right)$ or equilibrium partitioning $\left(\mathrm{HNO}_{3}(\mathrm{~g})+\mathrm{NH}_{3}(\mathrm{~g}) \leftrightarrow \mathrm{NH}_{4}^{+}(\mathrm{aq})+\mathrm{NO}_{3}^{-}(\mathrm{aq})\right)$ also contributed to the formation of nitrate under high $\mathrm{RH}$ conditions. This was supported by the fact that in Fig. 8 more plots were deviated from the regression line when RH levels were relatively high. The importance of heterogeneous reactions for nitrate formation were also reported in other studies (Sun et al., 2011; Zheng et al., 2015).

\subsection{Regional sources deduced from trajectory and PSCF analyses}

The regional sources and transport of air pollutants exert a profound impact on local air quality in the YRD region as it is located in the typical monsoon region (Ding et al., 2013). Therefore, a trajectory clustering method was employed to examine the pathway of air masses and to look into the chemical composition and light extinction coefficients among the air masses with different origination. The calculated $48 \mathrm{~h}$ back trajectories were clustered into six clusters (Fig. 9 and Table 1), i.e., six air mass transport pathways. As can be seen, air masses reaching Suzhou mainly came from local areas, the nearby provinces (cluster 2, accounting for $31.7 \%$ ), and the northwestern areas (cluster 1 and 3, both accounting for $20.6 \%)$.

High aerosol concentrations were associated with these trajectories. This was reasonable considering that these air masses passed over some highly industrialized cities, such as Hefei, Nanjing, and Hangzhou (Fig. 1). Relatively low levels of $\mathrm{PM}_{2.5}$ were related to clusters 5 and 6 . Based on the pathways and origins, these air masses were expected to bring in relatively clean air from the East China Sea and the Yellow Sea and consequently reduced the aerosol pollution in Suzhou.

Aerosols had high fractions of secondary inorganic ions (39-42\%) and relatively low contributions of OC (15-16\%) 

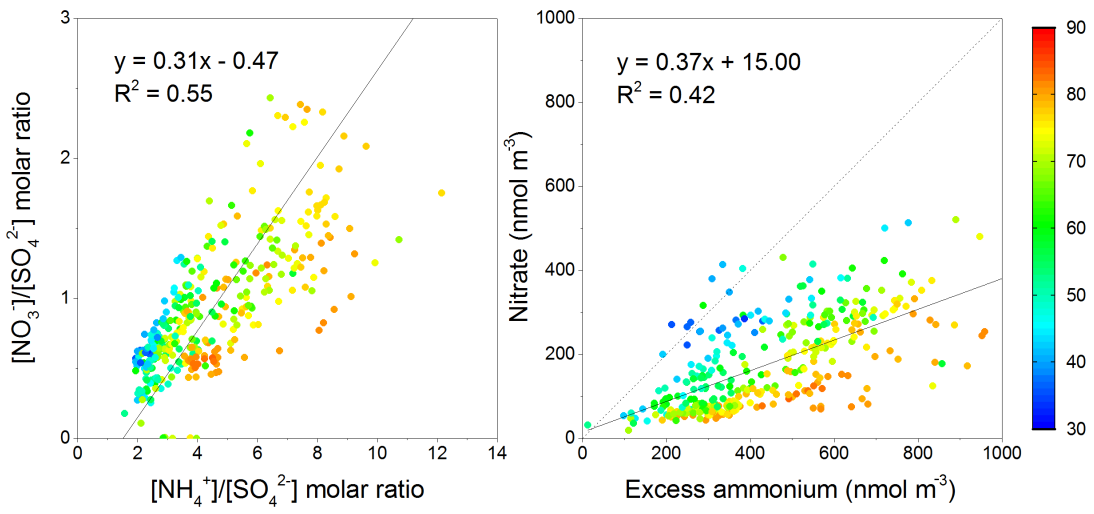

Figure 8. Nitrate to sulfate molar ratio as a function of ammonium to sulfate molar ratio (left) and the relationship between molar concentrations of nitrate and excess ammonium (right).

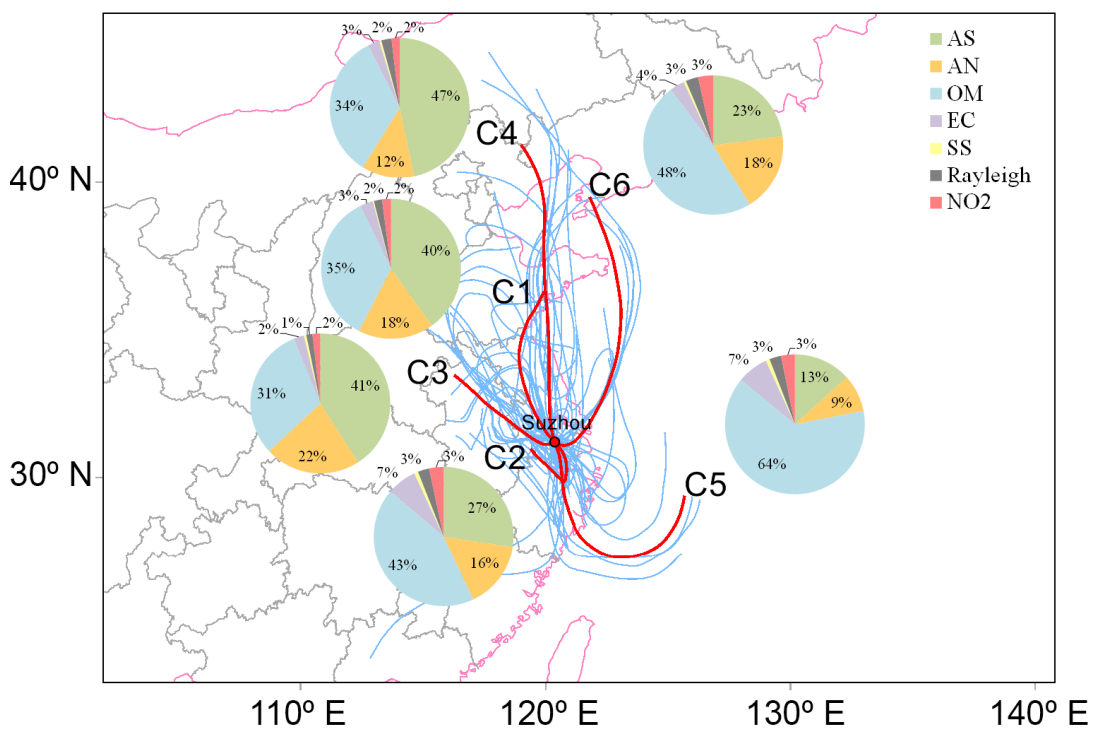

Figure 9. Backward air mass trajectories and six mean trajectories after the cluster analysis at the sampling site during 17 to 31 January. Relative contributions of various chemical components to the total light extinction in different clusters are illustrated.

when the air masses were in $\mathrm{C} 1, \mathrm{C} 3$, and $\mathrm{C} 4$, while they had a relatively high percentage of OC (36\%) when the air masses were in $\mathrm{C} 5$. These differences of aerosol concentrations and composition in different clusters may result in distinct light extinction coefficients and species contributions to visibility reduction when air masses originated from different directions (Fig. 9). Similar to $\mathrm{PM}_{2.5}$, the reconstructed $b_{\text {ext }}$ was the highest when air masses originated from the northwestern area (C3) and was relatively low when air masses were in $\mathrm{C} 5$ and C6 areas. However, the lowest value of $b_{\text {ext }}$ was in C6 instead of $\mathrm{C} 5$ for the lowest $\mathrm{PM}_{2.5}$ level because of the higher contribution of $\mathrm{OM}$ in $\mathrm{C} 5$. Ammonium sulfate and $\mathrm{OM}$ were the dominant species determining the light extinction for all clusters. However, AS was the predominant contributor to light extinction for trajectories from northern and northwestern areas $(\mathrm{C} 1, \mathrm{C} 3, \mathrm{C} 4)$, while in other cases the light extinc- tion was primarily affected by OM. AN was the third highest contributor in all trajectory clusters with the largest contribution when air masses originated from northwestern areas.

The origins of air masses in different haze events were further analyzed to interpret the relative contributions of chemical species to visibility reduction that differed between haze events. Most air masses were in $\mathrm{C} 1$ and $\mathrm{C} 3$ (air masses from northern and northwestern areas, respectively) in the first two haze occurrences, while all air mass trajectories were in $\mathrm{C} 2$ (air masses from local and nearby areas) for the third haze event. The contribution of $\mathrm{OM}$ to the total light extinction was higher in the third haze event than in the first two as discussed earlier, consistent with the results for cluster analysis that the light extinction was primarily impacted by AS for $\mathrm{C} 1$ and $\mathrm{C} 3$ but by $\mathrm{OM}$ for $\mathrm{C} 2$. These results showed that the third 

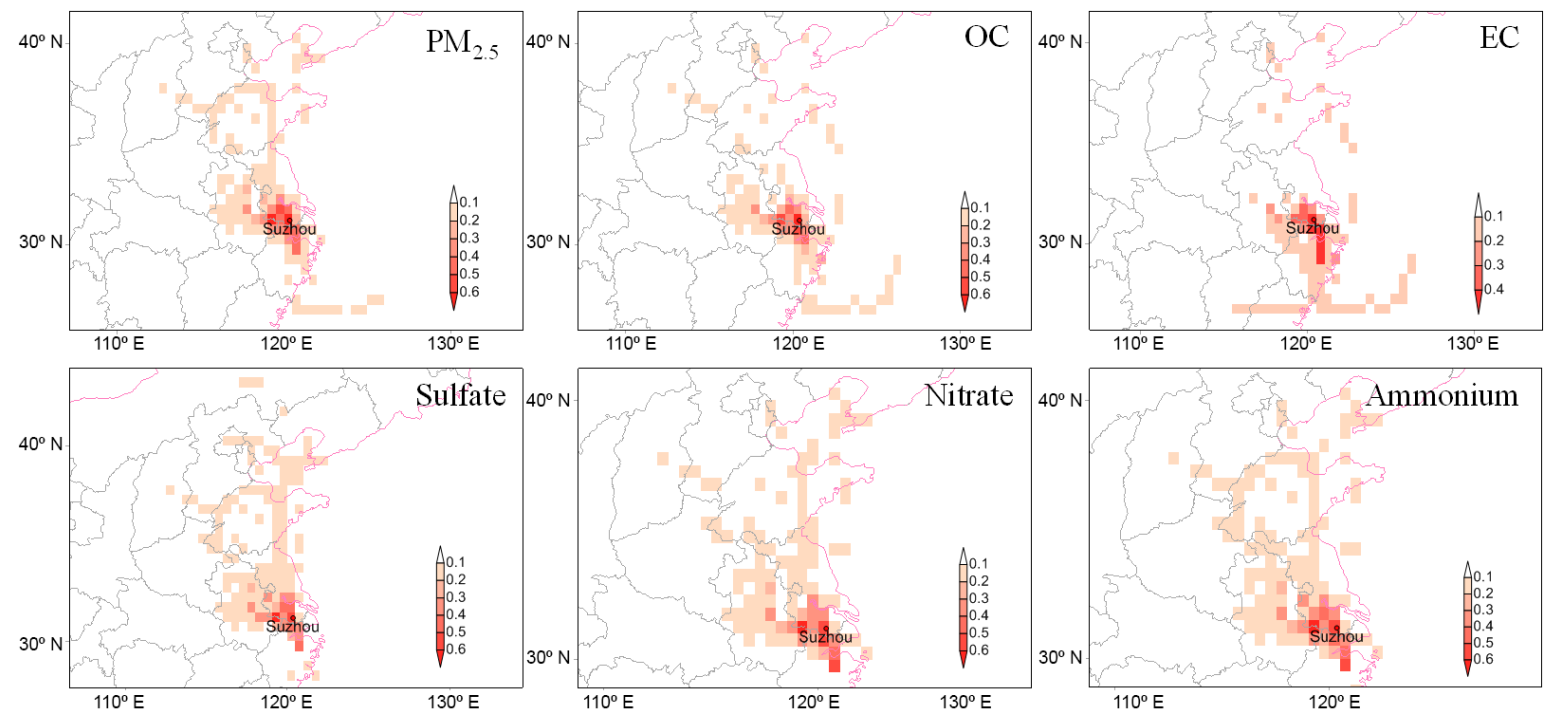

Figure 10. The PSCF maps for $\mathrm{PM}_{2.5}$, OC, EC, sulfate, nitrate, and ammonium.

haze event was mainly contributed by the primary emission of carbon species from the local and/or surrounding areas.

It should be noted that air mass back trajectory analysis only suggests the origination and pathways of air masses but does not directly reveal the exact sources. Based on the results of trajectory analysis, the PSCF method was applied to explore the likely regional sources of major components in $\mathrm{PM}_{2.5}$, including sulfate, nitrate, $\mathrm{OC}$, and $\mathrm{EC}$, as illustrated in Fig. 10. Generally, $\mathrm{PM}_{2.5}$ and the five aerosol species in Suzhou were mainly affected by local sources and nearby cities. Specifically, the higher value for $\mathrm{PM}_{2.5}$ and the aerosol components were all localized in northwestern to southern areas, covering surrounding cities in Jiangsu and near the border of Anhui and Zhejiang provinces. Additionally, these species were all affected by pollution from Anhui province. Sulfate, nitrate, and ammonium had similar spatial distributions, and were relatively more affected by the north and northwestern cities in Shandong, Jiangsu and Anhui provinces, while pollution from south cities in Zhejiang province had more impact on OC and EC in the studied area than sulfate, nitrate, and ammonium.

\section{Conclusions}

Heavy aerosol pollution occurred in Suzhou in January 2013 with daily $\mathrm{PM}_{2.5}$ concentrations on haze days 1.97 to 2.61 times higher than Grade II criteria of the national ambient air quality standard $\left(75 \mu \mathrm{g} \mathrm{m}^{-3}\right)$ and maximum value of $324 \mu \mathrm{g} \mathrm{m}^{-3}$ on 14 January 2013 . Unfavorable weather conditions (high RH, low rainfall, wind speed, and atmospheric pressure) especially high RH together with increased air pollutants produced from local and nearly sources, were responsible for these haze formations.
During the first two haze periods, the major aerosol components were $\mathrm{SO}_{4}^{2-}, \mathrm{NO}_{3}^{-}, \mathrm{NH}_{4}^{+}$, and $\mathrm{SOC}$, which were mainly from secondary sources. Furthermore, SOR and NOR both increased under worst visibility conditions, revealing efficient gas to particle conversion. Additionally, the contributions of $\left(\mathrm{NH}_{4}\right)_{2} \mathrm{SO}_{4}$ and $\mathrm{NH}_{4} \mathrm{NO}_{3}$ to the reconstructed $b_{\text {ext }}$ based on IMPROVE were higher under low visibility conditions, while those of $\mathrm{OM}$ and $\mathrm{EC}$ were higher under high visibility conditions, indicating that secondary inorganic aerosols, especially $\mathrm{NH}_{4} \mathrm{NO}_{3}$, seemed to be very influential in impaired visibility. Gas-phase homogeneous reactions might dominate the formation of sulfate and nitrate under low RH conditions, while the heterogeneous process might be responsible when RH levels were relatively high.

Distinctively, a high proportion of carbon species from primary emissions and a lower fraction of secondary formation components were observed in the third haze event. The SOR and NOR during the third haze episode were comparable to clean days. Moreover, increasing proportions of $\mathrm{OM}$ and $\mathrm{EC}$ accompanied with a decreasing percentage of $\left(\mathrm{NH}_{4}\right)_{2} \mathrm{SO}_{4}$ were found under worst visibility conditions when the third haze occurred. These results suggested that the carbon components from the primary emission might be relatively important for the visibility reduction for this haze event.

Trajectory clustering analysis showed that the air quality in Suzhou was mostly affected by air masses originating from northern and southwestern areas which were associated with high aerosol concentrations. Distinct aerosol composition profiles, light extinction coefficients, and species contributions to visibility reduction were observed when air masses originated from different directions; e.g., AS was the predominant contributor to light extinction for trajectories from northern and northwestern areas, while in other cases, the light extinction was primarily affected by OM. 
The likely sources of aerosol and the major species based on the PSCF method were mainly from local anthropogenic activities and source emissions transported from nearby cities. The northwestern to southern regions may be important sources of aerosols and the major components. The northern and northwestern areas were predominant source regions for sulfate, nitrate, and ammonium aerosols, whereas the southern area could be the common source region for carbonaceous species. This information has implications for the importance of collaborative air pollution control strategies in the Yangtze River Delta region.

\section{Data availability}

The NOAA HYSPLIT model is available at http://ready. arl.noaa.gov/HYSPLIT_traj.php (Stein et al., 2015; Rolph, 2016) and the E-AIM model is available at http://www.aim. env.uea.ac.uk/aim/aim.php (E-AIM, 2016). The concentrations of five conventional species (such as $\mathrm{SO}_{2}, \mathrm{NO}_{2}, \mathrm{O}_{3}$, $\mathrm{CO}$, and $\mathrm{PM}_{2.5}$ ) are accessible from http://222.92.77.250/ HuiMaiReporting/AQIOfHour.aspx.

Acknowledgements. This work was supported by the National Natural Science Foundation of China projects (41403089, 41375123), the Strategic Priority Research Program of the Chinese Academy of Sciences (KJZD-EW-TZ-G06-04), and the State Environmental Protection Key Laboratory of Sources and Control of Air Pollution Complex (SCAPC201310). We gratefully acknowledge the NOAA Air Resources Laboratory (ARL) for provision of the HYSPLIT trajectory model.

Edited by: S. S. Gunthe

\section{References}

Antony Chen, L. W., Doddridge, B. G., Dickerson, R. R., Chow, J. C., Mueller, P. K., Quinn, J., and Butler, W. A.: Seasonal variations in elemental carbon aerosol, carbon monoxide and sulfur dioxide: Implications for sources, Geophys. Res. Lett., 28, 17111714, doi:10.1029/2000g1012354, 2001.

Arimoto, R., Duce, R. A., Savoie, D. L., Prospero, J. M., Talbot, R., Cullen, J. D., Tomza, U., Lewis, N. F., and Jay, B. J.: Relationships among aerosol constituents from Asia and the North Pacific during PEM-West A, J. Geophys. Res.-Atmos., 101, 2011-2023, doi:10.1029/95jd01071, 1996.

Ashbaugh, L. L., Malm, W. C., and Sadeh, W. Z.: A residence time probability analysis of sulfur concentrations at Grand-Canyon-National-Park, Atmos. Environ., 19, 1263-1270, doi:10.1016/0004-6981(85)90256-2, 1985.

Bae, M.-S., Schauer, J. J., DeMinter, J. T., Turner, J. R., Smith, D., and Cary, R. A.: Validation of a semi-continuous instrument for elemental carbon and organic carbon using a thermal-optical method, Atmos. Environ., 38, 2885-2893, doi:10.1016/j.atmosenv.2004.02.027, 2004.
Castro, L. M., Pio, C. A., Harrison, R. M., and Smith, D. J. T. Carbonaceous aerosol in urban and rural European atmospheres: estimation of secondary organic carbon concentrations, Atmos. Environ., 33, 2771-2781, doi:10.1016/S1352-2310(98)00331-8, 1999.

Charlson, R. J., Lovelock, J. E., Andreae, M. O., and Warren, S. G.: Oceanic phytoplankton, atmospheric sulfur, cloud albedo and climate, Nature, 326, 655-661, doi:10.1038/326655a0, 1987.

Chen, J., Zhao, C. S., Ma, N., Liu, P. F., Göbel, T., Hallbauer, E., Deng, Z. Z., Ran, L., Xu, W. Y., Liang, Z., Liu, H. J., Yan, P., Zhou, X. J., and Wiedensohler, A.: A parameterization of low visibilities for hazy days in the North China Plain, Atmos. Chem. Phys., 12, 4935-4950, doi:10.5194/acp-12-4935-2012, 2012.

Chen, R., Zhao, Z., and Kan, H.: Heavy smog and hospital visits in Beijing, China, Am. J. Respir. Crit. Care, 188, 1170-1171, doi:10.1164/rccm.201304-0678LE, 2013.

Chow, J. C., Doraiswamy, P., Watson, J. G., Antony-Chen, L. W., Ho, S. S. H., and Sodeman, D. A.: Advances in integrated and continuous measurements for particle mass and chemical, composition, J. Air Waste Manage. Assoc., 58, 141-163, doi:10.3155/1047-3289.58.2.141, 2008.

Clegg, S. L., Brimblecombe, P., and Wexler, A. S.: Thermodynamic model of the system $\mathrm{H}^{+}-\mathrm{NH}_{4}^{+}-\mathrm{SO}_{4}^{2-}-\mathrm{NO}_{3}^{-}-\mathrm{H}_{2} \mathrm{O}$ at tropospheric temperatures, J. Phys. Chem. A, 102, 2137-2154, doi:10.1021/jp973042r, 1998.

Ding, A. J., Fu, C. B., Yang, X. Q., Sun, J. N., Zheng, L. F., Xie, Y. N., Herrmann, E., Nie, W., Petäjä, T., Kerminen, V.-M., and Kulmala, M.: Ozone and fine particle in the western Yangtze River Delta: an overview of $1 \mathrm{yr}$ data at the SORPES station, Atmos. Chem. Phys., 13, 5813-5830, doi:10.5194/acp-13-58132013, 2013.

E-AIM: Extended AIM Aerosol Thermodynamics Model, available at: http://www.aim.env.uea.ac.uk/aim/aim.php, last access: 10 June 2016.

Fang, G. C., Chang, C. N., Wu, Y. S., Fu, P. P. C., Yang, C. J., Chen, C. D., and Chang, S. C.: Ambient suspended particulate matters and related chemical species study in central Taiwan, Taichung during 1998-2001, Atmos. Environ., 36, 1921-1928, doi:10.1016/S1352-2310(02)00187-5, 2002.

Fu, Q., Zhuang, G., Wang, J., Xu, C., Huang, K., Li, J., Hou, B., Lu, T., and Streets, D. G.: Mechanism of formation of the heaviest pollution episode ever recorded in the Yangtze River Delta, China, Atmos. Environ., 42, 2023-2036, doi:10.1016/j.atmosenv.2007.12.002, 2008.

Gao, J., Tian, H., Cheng, K., Lu, L., Zheng, M., Wang, S., Hao, J., Wang, K., Hua, S., Zhu, C., and Wang, Y.: The variation of chemical characteristics of $\mathrm{PM}_{2.5}$ and $\mathrm{PM}_{10}$ and formation causes during two haze pollution events in urban Beijing, China, Atmos. Environ., 107, 1-8, doi:10.1016/j.atmosenv.2015.02.022, 2015.

Han, S., Wu, J., Zhang, Y., Cai, Z., Feng, Y., Yao, Q., Li, X., Liu, Y., and Zhang, M.: Characteristics and formation mechanism of a winter haze-fog episode in Tianjin, China, Atmos. Environ., 98, 323-330, doi:10.1016/j.atmosenv.2014.08.078, 2014.

He, K., Zhao, Q., Ma, Y., Duan, F., Yang, F., Shi, Z., and Chen, G.: Spatial and seasonal variability of $\mathrm{PM}_{2.5}$ acidity at two Chinese megacities: insights into the formation of secondary inorganic aerosols, Atmos. Chem. Phys., 12, 1377-1395, doi:10.5194/acp12-1377-2012, 2012. 
Hewitt, C. N.: The atmospheric chemistry of sulphur and nitrogen in power station plumes, Atmos. Environ., 35, 1155-1170, doi:10.1016/S1352-2310(00)00463-5, 2001.

Hsu, Y. K., Holsen, T. M., and Hopke, P. K.: Comparison of hybrid receptor models to locate PCB sources in Chicago, Atmos. Environ., 37, 545-562, doi:10.1016/S1352-2310(02)00886-5, 2003.

Hu, M., He, L. Y., Zhang, Y. H., Wang, M., Kim, Y. P., and Moon, K. C.: Seasonal variation of ionic species in fine particles at Qingdao, China, Atmos. Environ., 36, 5853-5859, doi:10.1016/S1352-2310(02)00581-2, 2002a.

Hu, M., Zhou, F., Shao, K., Zhang, Y., Tang, X., and Slanina, J.: Diurnal variations of aerosol chemical compositions and related gaseous pollutants in Beijing and Guangzhou, J. Environ. Sci. Heal. A, 37, 479-488, doi:10.1081/ese-120003229, 2002b.

Hua, W., Chen, Z. M., Jie, C. Y., Kondo, Y., Hofzumahaus, A., Takegawa, N., Chang, C. C., Lu, K. D., Miyazaki, Y., Kita, K., Wang, H. L., Zhang, Y. H., and Hu, M.: Atmospheric hydrogen peroxide and organic hydroperoxides during PRIDE-PRD'06, China: their concentration, formation mechanism and contribution to secondary aerosols, Atmos. Chem. Phys., 8, 6755-6773, doi:10.5194/acp-8-6755-2008, 2008.

Huang, R. J., Zhang, Y., Bozzetti, C., Ho, K. F., Cao, J. J., Han, Y., Daellenbach, K. R., Slowik, J. G., Platt, S. M., Canonaco, F., Zotter, P., Wolf, R., Pieber, S. M., Bruns, E. A., Crippa, M., Ciarelli, G., Piazzalunga, A., Schwikowski, M., Abbaszade, G., SchnelleKreis, J., Zimmermann, R., An, Z., Szidat, S., Baltensperger, U., El Haddad, I., and Prevot, A. S.: High secondary aerosol contribution to particulate pollution during haze events in China, Nature, 514, 218-222, doi:10.1038/nature13774, 2014.

Jansen, R. C., Shi, Y., Chen, J., Hu, Y., Xu, C., Hong, S., Li, J., and Zhang, M.: Using hourly measurements to explore the role of secondary inorganic aerosol in $\mathrm{PM}_{2.5}$ during haze and fog in Hangzhou, China, Adv. Atmos. Sci., 31, 1427-1434, doi:10.1007/s00376-014-4042-2, 2014.

Ji, D., Li, L., Wang, Y., Zhang, J., Cheng, M., Sun, Y., Liu, Z., Wang, L., Tang, G., Hu, B., Chao, N., Wen, T., and Miao, H.: The heaviest particulate air-pollution episodes occurred in northern China in January, 2013: Insights gained from observation, Atmos. Environ., 92, 546-556, doi:10.1016/j.atmosenv.2014.04.048, 2014.

Khoder, M. I.: Atmospheric conversion of sulfur dioxide to particulate sulfate and nitrogen dioxide to particulate nitrate and gaseous nitric acid in an urban area, Chemosphere, 49, 675-684, doi:10.1016/S0045-6535(02)00391-0, 2002.

Li, W., Zhou, S., Wang, X., Xu, Z., Yuan, C., Yu, Y., Zhang, Q., and Wang, W.: Integrated evaluation of aerosols from regional brown hazes over northern China in winter: Concentrations, sources, transformation, and mixing states, J. Geophys. Res., 116, D09301, doi:10.1029/2010jd015099, 2011.

Pathak, R. K., Wu, W. S., and Wang, T.: Summertime $\mathrm{PM}_{2.5}$ ionic species in four major cities of China: nitrate formation in an ammonia-deficient atmosphere, Atmos. Chem. Phys., 9, 17111722, doi:10.5194/acp-9-1711-2009, 2009.

Pathak, R. K., Wang, T., and Wu, W. S.: Nighttime enhancement of $\mathrm{PM}_{2.5}$ nitrate in ammonia-poor atmospheric conditions in Beijing and Shanghai: Plausible contributions of heterogeneous hydrolysis of $\mathrm{N}_{2} \mathrm{O}_{5}$ and $\mathrm{HNO}_{3}$ partitioning, Atmos. Environ., 45, 1183-1191, doi:10.1016/j.atmosenv.2010.09.003, 2011.

Pitchford, M., Maim, W., Schichtel, B., Kumar, N., Lowenthal, D., and Hand, J.: Revised algorithm for estimating light extinc- tion from IMPROVE particle speciation data, J. Air Waste Manage. Assoc., 57, 1326-1336, doi:10.3155/1047-3289.57.11.1326, 2007.

Polissar, A. V., Hopke, P. K., Paatero, P., Kaufmann, Y. J., Hall, D. K., Bodhaine, B. A., Dutton, E. G., and Harris, J. M.: The aerosol at Barrow, Alaska: long-term trends and source locations, Atmos. Environ., 33, 2441-2458, doi:10.1016/S1352-2310(98)00423-3, 1999.

Quan, J., Tie, X., Zhang, Q., Liu, Q., Li, X., Gao, Y., and Zhao, D.: Characteristics of heavy aerosol pollution during the 20122013 winter in Beijing, China, Atmos. Environ., 88, 83-89, doi:10.1016/j.atmosenv.2014.01.058, 2014.

Ramanathan, V. and Vogelmann, A. M.: Greenhouse effect, atmospheric solar absorption and the Earth's radiation budget: From the Arrhenius-Langley era to the 1990s, Ambio, 26, 38-46, 1997.

Rolph, G. D.: Real-time Environmental Applications and Display sYstem (READY) Website, available at: http://www.ready.noaa gov (last access: 10 June 2016), NOAA Air Resources Laboratory, College Park, MD, 2016.

Seinfeld, J. H. and Pandis, S. N.: Atmospheric Chemistry and Physics: From Air Pollution to Climate Change, 2nd Edn., John Wiley \& Sons, Hoboken, New Jersey, 2012.

Stein, A. F., Draxler, R. R., Rolph, G. D., Stunder, B. J. B., Cohen, M. D., and Ngan, F.: NOAA's HYSPLIT atmospheric transport and dispersion modeling system, B. Am. Meteorol. Soc., 96 , 2059-2077, doi:10.1175/BAMS-D-14-00110.1, 2015.

Sun, Y., Zhuang, G., Tang, A., Wang, Y., and An, Z.: Chemical Characteristics of $\mathrm{PM}_{2.5}$ and $\mathrm{PM}_{10}$ in Haze-Fog Episodes in Beijing, Environ. Sci. Technol., 40, 3148-3155, doi:10.1021/es051533g, 2006.

Sun, Y., Jiang, Q., Wang, Z., Fu, P., Li, J., Yang, T., and Yin, Y.: Investigation of the sources and evolution processes of severe haze pollution in Beijing in January 2013, J. Geophys. Res.-Atmos., 119, 4380-4398, doi:10.1002/2014jd021641, 2014.

Sun, Y. L., Zhang, Q., Schwab, J. J., Chen, W. N., Bae, M. S., Lin, Y. C., Hung, H. M., and Demerjian, K. L.: A case study of aerosol processing and evolution in summer in New York City, Atmos. Chem. Phys., 11, 12737-12750, doi:10.5194/acp11-12737-2011, 2011.

Sun, Y. L., Wang, Z. F., Fu, P. Q., Jiang, Q., Yang, T., Li, J., and Ge, X. L.: The impact of relative humidity on aerosol composition and evolution processes during wintertime in Beijing, China, Atmos. Environ., 77, 927-934, doi:10.1016/j.atmosenv.2013.06.019, 2013a.

Sun, Y. L., Wang, Z. F., Fu, P. Q., Yang, T., Jiang, Q., Dong, H. B., Li, J., and Jia, J. J.: Aerosol composition, sources and processes during wintertime in Beijing, China, Atmos. Chem. Phys., 13, 4577-4592, doi:10.5194/acp-13-4577-2013, 2013 b.

Tan, J., Duan, J., He, K., Ma, Y., Duan, F., Chen, Y., and Fu, J.: Chemical characteristics of $\mathrm{PM}_{2.5}$ during a typical haze episode in Guangzhou, J. Environ. Sci., 21, 774-781, doi:10.1016/s10010742(08)62340-2, 2009.

Tao, J., Zhang, L. M., Ho, K. F., Zhang, R. J., Lin, Z. J., Zhang, Z. S., Lin, M., Cao, J. J., Liu, S. X., and Wang, G. H.: Impact of $\mathrm{PM}_{2.5}$ chemical compositions on aerosol light scattering in Guangzhou - the largest megacity in South China, Atmos. Res., 135, 48-58, doi:10.1016/j.atmosres.2013.08.015, 2014.

Tao, J., Zhang, L., Gao, J., Wang, H., Chai, F., and Wang, S.: Aerosol chemical composition and light scattering dur- 
ing a winter season in Beijing, Atmos. Environ., 110, 36-44, doi:10.1016/j.atmosenv.2015.03.037, 2015.

Tegen, I., Koch, D., Lacis, A. A., and Sato, M.: Trends in tropospheric aerosol loads and corresponding impact on direct radiative forcing between 1950 and 1990: A model study, J. Geophys. Res.-Atmos., 105, 26971-26989, doi:10.1029/2000jd900280, 2000.

Tie, X., Madronich, S., Li, G., Ying, Z., Weinheimer, A., Apel, E., and Campos, T.: Simulation of Mexico City plumes during the MIRAGE-Mex field campaign using the WRF-Chem model, Atmos. Chem. Phys., 9, 4621-4638, doi:10.5194/acp-9-4621-2009, 2009a.

Tie, X., Wu, D., and Brasseur, G.: Lung cancer mortality and exposure to atmospheric aerosol particles in Guangzhou, China, Atmos. Environ., 43, 2375-2377, doi:10.1016/j.atmosenv.2009.01.036, 2009b.

Trebs, I., Meixner, F. X., Slanina, J., Otjes, R., Jongejan, P., and Andreae, M. O.: Real-time measurements of ammonia, acidic trace gases and water-soluble inorganic aerosol species at a rural site in the Amazon Basin, Atmos. Chem. Phys., 4, 967-987, doi:10.5194/acp-4-967-2004, 2004.

Wang, H., An, J., Shen, L., Zhu, B., Pan, C., Liu, Z., Liu, X., Duan, Q., Liu, X., and Wang, Y.: Mechanism for the formation and microphysical characteristics of submicron aerosol during heavy haze pollution episode in the Yangtze River Delta, China, Sci. Total Environ., 490, 501-508, doi:10.1016/j.scitotenv.2014.05.009, 2014a.

Wang, H., Xu, J., Zhang, M., Yang, Y., Shen, X., Wang, Y., Chen, D., and Guo, J.: A study of the meteorological causes of a prolonged and severe haze episode in January 2013 over central-eastern China, Atmos. Environ., 98, 146-157, doi:10.1016/j.atmosenv.2014.08.053, 2014b.

Wang, J., Wang, S., Jiang, J., Ding, A., Zheng, M., Zhao, B., Wong, D. C., Zhou, W., Zheng, G., Wang, L., Pleim, J. E., and Hao, J.: Impact of aerosol-meteorology interactions on fine particle pollution during China's severe haze episode in January 2013, Environ. Res. Lett., 9, 094002, doi:10.1088/1748-9326/9/9/094002, 2014.

Wang, Y., Zhuang, G. S., Tang, A. H., Yuan, H., Sun, Y. L., Chen, S. A., and Zheng, A. H.: The ion chemistry and the source of $\mathrm{PM}_{2.5}$ aerosol in Beijing, Atmos. Environ., 39, 3771-3784, doi:10.1016/j.atmosenv.2005.03.013, 2005.

Wang, Y., Zhuang, G., Sun, Y., and An, Z.: The variation of characteristics and formation mechanisms of aerosols in dust, haze, and clear days in Beijing, Atmos. Environ., 40, 6579-6591, doi:10.1016/j.atmosenv.2006.05.066, 2006.

Wang, Y., Yao, L., Wang, L., Liu, Z., Ji, D., Tang, G., Zhang, J., Sun, Y., Hu, B., and Xin, J.: Mechanism for the formation of the January 2013 heavy haze pollution episode over central and eastern China, Sci. China-Earth Sci., 57, 14-25, doi:10.1007/s11430013-4773-4, 2014.

Wang, Y. H., Liu, Z. R., Zhang, J. K., Hu, B., Ji, D. S., Yu, Y. C., and Wang, Y. S.: Aerosol physicochemical properties and implications for visibility during an intense haze episode during winter in Beijing, Atmos. Chem. Phys., 15, 3205-3215, doi:10.5194/acp-15-3205-2015, 2015.

Wang, Y. Q., Zhang, X. Y., and Draxler, R. R.: TrajStat: GISbased software that uses various trajectory statistical analysis methods to identify potential sources from long-term air pollu- tion measurement data, Environ. Modell. Softw., 24, 938-939, doi:10.1016/j.envsoft.2009.01.004, 2009.

Warneck, P.: Chemistry of the natural atmosphere, Academic press, San Diego, 1999.

Wehner, B., Birmili, W., Ditas, F., Wu, Z., Hu, M., Liu, X., Mao, J., Sugimoto, N., and Wiedensohler, A.: Relationships between submicrometer particulate air pollution and air mass history in Beijing, China, 2004-2006, Atmos. Chem. Phys., 8, 6155-6168, doi:10.5194/acp-8-6155-2008, 2008.

Xiao, H. Y. and Liu, C. Q.: Chemical characteristics of water-soluble components in TSP over Guiyang, SW China, 2003, Atmos. Environ., 38, 6297-6306, doi:10.1016/j.atmosenv.2004.08.033, 2004.

Yang, F. M., He, K. B., Ma, Y. L., Zhang, Q., Cadle, S. H., Chan, T., and Mulawa, P. A.: Characterization of carbonaceous species of ambient $\mathrm{PM}_{2.5}$ in Beijing, China, J. Air Waste Manage. Assoc., 55, 984-992, doi:10.1080/10473289.2005.10464699, 2005.

Yang, Y., Liu, X., Qu, Y., Wang, J., An, J., Zhang, Y., and Zhang, F.: Formation mechanism of continuous extreme haze episodes in the megacity Beijing, China, in January 2013, Atmos. Res., 155, 192-203, doi:10.1016/j.atmosres.2014.11.023, 2015.

Yao, X. H., Chan, C. K., Fang, M., Cadle, S., Chan, T., Mulawa, P., He, K. B., and Ye, B. M.: The water-soluble ionic composition of $\mathrm{PM}_{2.5}$ in Shanghai and Beijing, China, Atmos. Environ., 36, 4223-4234, doi:10.1016/S1352-2310(02)00342-4, 2002.

Yu, H. B., Liu, S. C., and Dickinson, R. E.: Radiative effects of aerosols on the evolution of the atmospheric boundary layer, J. Geophys. Res.-Atmos., 107, AAC 3-1-AAC 3-14, doi:10.1029/2001jd000754, 2002.

Yu, S., Zhang, Q., Yan, R., Wang, S., Li, P., Chen, B., Liu, W., and Zhang, X.: Origin of air pollution during a weekly heavy haze episode in Hangzhou, China, Environ. Chem. Lett., 12, 543-550, doi:10.1007/s10311-014-0483-1, 2014.

Zhang, J., Chen, J., Yang, L., Sui, X., Yao, L., Zheng, L., Wen, L., $\mathrm{Xu}, \mathrm{C}$., and Wang, W.: Indoor $\mathrm{PM}_{2.5}$ and its chemical composition during a heavy haze-fog episode at Jinan, China, Atmos. Environ., 99, 641-649, doi:10.1016/j.atmosenv.2014.10.026, 2014.

Zhang, Q., Quan, J., Tie, X., Li, X., Liu, Q., Gao, Y., and Zhao, D.: Effects of meteorology and secondary particle formation on visibility during heavy haze events in Beijing, China, Sci. Total Environ., 502, 578-584, doi:10.1016/j.scitotenv.2014.09.079, 2015.

Zhang, X. Y., Wang, Y. Q., Niu, T., Zhang, X. C., Gong, S. L., Zhang, Y. M., and Sun, J. Y.: Atmospheric aerosol compositions in China: spatial/temporal variability, chemical signature, regional haze distribution and comparisons with global aerosols, Atmos. Chem. Phys., 12, 779-799, doi:10.5194/acp12-779-2012, 2012.

Zhao, X. J., Zhao, P. S., Xu, J., Meng,, W., Pu, W. W., Dong, F., He, D., and Shi, Q. F.: Analysis of a winter regional haze event and its formation mechanism in the North China Plain, Atmos. Chem. Phys., 13, 5685-5696, doi:10.5194/acp-13-5685-2013, 2013.

Zheng, G. J., Duan, F. K., Su, H., Ma, Y. L., Cheng, Y., Zheng, B., Zhang, Q., Huang, T., Kimoto, T., Chang, D., Pöschl, U., Cheng, Y. F., and He, K. B.: Exploring the severe winter haze in Beijing: the impact of synoptic weather, regional transport and heterogeneous reactions, Atmos. Chem. Phys., 15, 2969-2983, doi:10.5194/acp-15-2969-2015, 2015. 